A. Rahmatian (2015), 'The elements of music relevant for copyright protection', in: A. Rahmatian (ed.), Concepts of Music and Copyright: How Music Perceives Itself and How Copyright Perceives Music (Cheltenham: Edward Elgar, 2015), pp. 78-122.

\title{
The Elements of Music relevant for Copyright Protection
}

\author{
(C) 2015, Dr Andreas Rahmatian, University of Glasgow
}

\section{[p. 78]}

$1 \quad$ Music as a living art: performance and text

The protection of music by copyright is a fascinating conglomerate of simplifying reconceptualisations, approximations and auxiliary measures that remodel the phenomenon of music in a way that renders it intelligible to the concepts of law. In truth, copyright law has no genuine understanding of the nature of music as an art form; ${ }^{1}$ it attaches to certain aspects of music which it declares as normatively relevant and thus ascertains building blocks of the legal protection system. Generally this method works satisfactorily, mainly because lawyers (and court decisions) frequently disregard the artistic phenomenon of music itself as a starting point for protection. They presuppose 'music' as a 'black box' and concentrate on, say, the score as a normatively relevant aspect for protection purposes. In most cases, however, their focus is on assignment and licensing rights in relation to specific musical works. In this way music is considered as an object of legal transactions, especially as an object of transferable property. This is a result of the translation process of music into legal categories. Here we look at the elements and stages of this process. We therefore have to start with some attempts at the definition and description of the phenomenon of music. [p. 79]

\footnotetext{
${ }^{1}$ See also Craig and Laroche (2014: 44-45).
} 


\subsection{Music and time}

Music is embellished time. ${ }^{2}$ I maintain this aphoristic definition ${ }^{3}$ and for present purposes I consider its inherent imprecisions as a virtue. One may render this definition more neutrally as 'music is fashioned time', but it is in the nature of music that this fashioning is always an enhancement (at least an intended one) of the time experience. ${ }^{4}$ Music has no clearly discernable aim beyond that, and the idea of 'enhancement' is deliberately diffuse. Time, supplemented by music, obtains an aesthetic quality: it is 'aesthetic time'. ${ }^{5}$ It is not directed at the existence and quality of a specific object or at a possible purpose. ${ }^{6}$ For the present conceptual discussion it is irrelevant whether a given individual does or does not like a specific piece of music. There is no need either to go into aesthetic discussions in the tradition of the eighteenth and nineteenth centuries as to what 'beautiful' really means, ${ }^{7}$ particularly with regard to music. ${ }^{8} \mathrm{We}$ will see later that aesthetic or artistic qualities are also irrelevant from a legal perspective. Both definitions assume, however, that the most fundamental constituent of music is time. This means, time is not just presupposed, but the art form of music must deal with the problem of time actively as part of making the art. ${ }^{9}$ Music can be seen as a temporal structure, not as a structure in time: the structure unfolds in time, this is its very nature. Time is not the framework for what happens in it (structure in time). Music is rather intrinsically a time-bound process [p. 80] (temporal structure). ${ }^{10}$ So music is a process as an aspect of time (dynamic), not an object or product within the framework of time (static), like a statue or an architectural work. Such objects are obviously also subjected to the influence of time (ageing etc.), but time is here framework, not constituting element. If we could stop time, there would be no music, but a statue would still be here, and even one image of a movement in a dance, although we would obviously not be able to perceive it and register the perception in our mind, as this would also require the flow of time.

\footnotetext{
${ }^{2}$ Even where the element of 'embellishment' is deliberately removed, for example in experiments with time frame by John Cage (e.g. his 4'33'") it still refers to that idea as a negation of it, and it is an inevitable emphasis of the element of time as the central constitutive factor.

${ }^{3}$ First in Rahmatian (2005: 272).

${ }^{4}$ From the perspective of a utilitarian or economist one could say: music is value-added time, but I refuse this terminology. On the 'aesthetic experience' of music, see Coker (1972: 24-28).

${ }^{5}$ Stambaugh (1964: 274). Whether this aesthetic quality is the primary aim (or an aim at all) of music in a given situation depends on the function of the specific piece of music (for dancing, worshipping, for example).

${ }^{6}$ This argument is influenced by Kant's discussion on the arts in general in his Critique of Judgment (Kritik der Urteilskraft), book 1 (Kant 1974: 129-134) [A24-32/B24-32].

${ }^{7}$ Kristeller (1952: 17).

${ }^{8}$ Scruton (1997: 369-379), Hanslick, Vom Musikalisch Schönen (1902: 72-83).

${ }^{9}$ Adorno, Über einige Relationen zwischen Musik und Malerei (2003a: 628).

${ }^{10}$ Stambaugh (1964: 266-267). See also Barron (2006: 39-40) quoting Herder and Humboldt on music as an art form that works 'in the sequence of time'.
} 
Husserl's transcendental phenomenology ${ }^{11}$ sees music as an example of the inner awareness of time. The event of a sound is superseded by the mental retention (memory) of the sound event that has just passed. So the present is extended beyond the physical event (the specific sound) by retention of the event in the immediate past and by pro-tention of the immediately expected event (the difference being that the retention corresponds to a fading of real experience, while the pro-tension relates to expectations that may or may not be fulfilled, and so does not directly correspond to real experience). According to Husserl perception operates in a fourfold sense: (a) the perception of, for instance, the whistle of a pipe, (b) the actual sound of the whistle as to its contents, especially duration and sound colour, (c) the present of the tone and the perception of the correlation of the tone with the tones of the immediate past, (d) the perception of the awareness of time in the present, e.g. the whistle tone appearing in the now. The immediate past is shadowed by the occurrence of the event in the present. ${ }^{12}$ Although one can never listen to a piece of music as a whole at the same time as one can look at a painting as a whole at the same time ${ }^{13}$ one nevertheless perceives the whole piece of music as a complete entity because one recognises the sounds of a [p. 81] melody in a correlation to one another. Only when the last sound fades away the piece is perceived as being in the past. ${ }^{14}$

\subsection{Music and space}

The central role of time in music is obvious. However, there are spatial qualities, in that, first of all, music sounds in a space. ${ }^{15}$ The sound expands in the air of a room, is subjected to acoustical refractions; there is a reverberation, an echo - all of which is central to the location of sounds and the musical experience of the listener and the musician alike. It appears here already that music means interaction between the sound and a listener, ${ }^{16}$ being the musician himself or the member of an audience. But apart from the acoustical phenomena in the physical space there is also a

\footnotetext{
${ }^{11}$ See Husserl, Ideen zu einer reinen Phänomenologie (2009: 6), for the definition of transcendental phenomenology as 'eidetic' science.

${ }^{12}$ Husserl, Phänomenologie des inneren Zeitbewußtseins (2000: 25-27, 63, 99, 101). On the reproduction of music heard at an earlier point in time, see Husserl (2000: 42-43).

${ }^{13}$ Because in case of a painting everything is at the same time, see Adorno, Über einige Relationen zwischen Musik und Malerei (2003a: 631). Even if one looks at a section of a musical score which comes closest to a depiction by an image a painting gives, the difference remains that a score reflects a visualised flow of time, while a (figurative) painting reflects a frozen visual scene, unless one considers the score as a graphic image, detached from its musical purpose.

${ }^{14}$ Husserl, Phänomenologie des inneren Zeitbewußtseins (2000: 32).

${ }^{15}$ Not according to Schopenhauer, Die Welt als Wille und Vorstellung, book 3, § 52 (2008: 352), for whom music is 'perceived solely and entirely in and through time, to the complete exclusion of the space.'

${ }^{16}$ Cook (1992: 10).
} 
psychological space. ${ }^{17}$ The perception of movement requires listening in a space (physical) but sound itself almost always appears as being in motion (psychological) as it really is physically (air waves). The frequency and the sound colour or timbre of a tone are also perceived in a notional 'space': high and bright tones higher up, low and dull tones lower down. ${ }^{18}$ But that is culturally dependent. African peoples would refer to low sounds as 'big' sounds and call high sounds 'small' sounds. ${ }^{19}$ This is nevertheless familiar to Western cultures: for example, in Prokofiev's Peter and the Wolf (1936) nobody would expect the big wolf being represented by the flute and the small bird by the lower registers of the French horn.

\subsection{Music and music notation}

The terms 'lower octaves' or 'higher octaves' also connote a certain spatiality, and in Western musical notation lower notes appear on the lower ledger lines of the stave. There is a notional (psychological) horizontal-spatial dimension in music, reinforced by the musical 'text', the characteristic pictorial music notation of Western music, as we know [p. 82] it from the usual music scores. This has prompted some musicologists to claim that there is a musical space in its own right and without it our familiar musical notation would not be possible. ${ }^{20} \mathrm{Be}$ it as it may, but the converse does not apply: non-Western classical and popular music can and does exist perfectly well without a too complex notation system, ${ }^{21}$ or indeed without any notation at all: ${ }^{22}$ traditional African music, for example, passes on its musical traditions through 'oral notation', a form of phonetic patterns and symbols which the musicians associate with syllables, words and meanings in the respective languages. ${ }^{23}$ Even Western classical music can perfectly well be taught through oral tradition, and in historically informed performance practices aspects of 'authentic' interpretation of early music, for example ornamentation, are indeed handed down orally to a significant extent, though fortified by academic research ${ }^{24}$ (and imitation/'imitatio' is an important factor in that 'oral' tradition at least). Music notation is not constitutive of music or music performance. It may, however, be constitutive of the composition of certain types of music in Western classical music in certain epochs, such as polyphonic music, ${ }^{25}$ especially in the Late Medieval, Renaissance and Baroque periods, where the notation was also part of

\footnotetext{
${ }^{17}$ Wellek (1963: 296-299).

${ }^{18}$ Hornbostel (1986: 317).

${ }^{19}$ Kubik (1988: 1000). The example is here from Southwest Africa, but applies to numerous peoples in many parts of Africa.

${ }^{20}$ Wellek (1963: 309).

${ }^{21}$ Such as in (Northern) Indian classical music, see Daniélou (1949: 49-57, 82-98).

${ }^{22}$ Nettl (1983: 65).

${ }^{23}$ Kubik (1988: 87-88).

${ }^{24}$ See, for example, Donington (1992: 236-266) on the trill and the mordent.

${ }^{25}$ Adorno, Über einige Relationen zwischen Musik und Malerei (2003a: 632).
} 
musical expression beyond the performative component. One can hardly imagine the development of the motet and other polyphonic music without notation. ${ }^{26}$ Classical teaching of musical composition requires the student to imagine the music to be composed without the aid of an instrument, so to develop the ability to compose music as an abstract idea first. ${ }^{27}$ In copyright law the score has a significant importance irrespective of the style and type of music. [p. 83]

\subsection{Performance and 'text'}

Music is a living, performative art. It exists in, and through, performance. The score, if there is any, is not the music. We will see that copyright law also recognises that. Musical pieces are not only the work of their composers; it is the performance and the opportunity to listen to the performance that renders the piece into a musical work. ${ }^{28}$ There is the presupposition that someone will hear the music (whether or not that happens in reality). ${ }^{29}$ However, there are also other views: what the author has created is already the work of music. ${ }^{30}$ In any case, the text of the score reflects the intention of the composer, but not conclusively, and 'intention' is a vague idea anyway. ${ }^{31}$ This touches upon the equally vague notion of the 'musical work' and the question of the limits of an 'appropriate' or 'authentic' performance of the musical work. ${ }^{32}$ With the beginning of the early romantic period, the role of the performer of music was formulated, especially by the great novelist E. T. A. Hoffmann (1776-1822) who was also a notable composer: for Hoffmann the real performer lives in the work of the composer which he has comprehended in the composer's spirit and which he seeks to perform in this way, thereby holding back his own personality. ${ }^{33}$ In classical music that is still the prevalent opinion. ${ }^{34}$ Different types of performances are still performances of the same work, presentations of the same edifice from different

\footnotetext{
${ }^{26}$ On the simultaneous nature of layers of the visual and aural texts of late-medieval motes, see e.g. Bent (1997: 82-84).

${ }^{27}$ Impressively A. B. Marx in his textbook on composition, Die Lehre von der musikalischen Komposition, vol. 1 (1868: 17). This presupposes the notion of an 'inner ear' that can 'hear' everything the notation shows.

${ }^{28}$ Gadamer (2003: 110); Kivy (1995: 147): 'A performance (product) of a work simply is the work, or (if you are a Platonist in these matters) an instance of the work.' (emphasis original).

${ }^{29}$ Butt (2010: 6).

${ }^{30}$ Wiora (2000: 24).

${ }^{31}$ Dahlhaus, Musiktheorie (1988: 100), Kivy (1995: 146). Besides this 'intention by the composer there is some kind of 'intentionality' in the production of the score and in the very symbols of the notation.

${ }^{32}$ Goehr (1989: 55-58), Kivy (2007: 93, 115). See also chapter 1 by John Butt, and briefly below under 3.

${ }^{33}$ Hoffmann, review of Two Trios for Pianoforte by Beethoven op. 70 (1988: 147).

${ }^{34}$ E.g. Brendel (2001: 367-368), on the idea of 'Werktreue' and reading music, ibid. (2001: 30, 32). See also Goehr (1989: 55).
} 
viewpoints, as it were. ${ }^{35}$ However, the particularly detailed and precise notation of modern scores of certain types of contemporary music [p. 84] (e.g. 'total serialism', in which every parameter of pitch, duration and expression is prescribed) can restrict the scope of interpretation extremely, so that the text or notation itself can be regarded as coming close to the realisation of the work. ${ }^{36}$ The problem of the division between composition and its performance is also relevant to copyright law, since the musical work and its interpretation attach to two separate sets of rights.

The text of the score is certainly the starting point for any performance. But the score can only be seen as an incomplete and imperfect representation of the music, a building instruction for the performance. ${ }^{37}$ Normative as the score is as the expression of the composer's intention, the symbols are only a limited aid to the reconstitution of the intended musical sound. During the reading the symbols have to be synthesised to an interpretation that translates the signs into sounds in the course of an inner hearing. ${ }^{38}$ That is very dependent on the familiarity of the reader with the type of music, and its historical and cultural context. ${ }^{39}$ So even a composer may not be able to read (silently) another composer's score if that other music is based on a completely different and unfamiliar conceptual structure. ${ }^{40}$ The same applies to music in several parts or voices, even where the style is well known, because the players in the orchestra or a string quartet must synthesise the different parts to a musical whole in an intelligent interpretation process which involves much mutual listening of the players. ${ }^{41}$ The listener is also part of the interpretation process, at least where she is the musician herself who reacts to the immediate auditory feedback. ${ }^{42}$ Music always happens between produced sound and listening ear or mind, that is, psychologically and sociologically, between player and listener. One can distinguish three different types of listeners (and music catering for these three [p. 85] types), the 'hearers', the 'intentional listeners', and the 'implied listeners' who create a specific self over the duration of the listening experience and map consciously the music in time. ${ }^{43}$

\footnotetext{
${ }^{35}$ Gadamer (2003: 118). A separate, but related, point is where a 'performance' departs so significantly from a 'right' representation, that the new work is derivative, or a variation of the pre-existing work, but artistically sufficiently independent. See below under 4 .

${ }^{36}$ Or, pointedly, it is the realisation already, according to Adorno, Musik und Technik (2003a: 233). Another example would be the fixation of 'tape music' in the late 1950s) which is fixed without even needing a score.

${ }^{37}$ Rahmatian (2005: 273).

${ }^{38}$ This is a process of understanding, both in the case of silent reading and of listening to performed music, see Gadamer (2003: 91).

${ }^{39}$ Cook (1992: 122-128).

${ }^{40}$ That was apparently the case with Gustav Mahler trying to make sense of Arnold Schoenberg's first string quartet which Schoenberg showed Mahler, see Cook (1992: 129), note 7.

${ }^{41}$ This has already been remarked by Hoffmann, review of Coriolan Ouverture by Beethoven op. 62 (1988: 102).

${ }^{42}$ Cook (1992: 10-11, 127); Gadamer (2003: 110) with the example of chamber music.

${ }^{43}$ Butt (2010: 8-9).
} 


\subsection{The philosophers' problem with the temporary, ineffable nature of music}

Philosophers generally had problems with the intangible, fleeting, ephemeral quality of music. Several philosophers have developed ideas about music, few really competently (particularly Rousseau and Adorno), and only in very few cases music was a central part of their philosophical system. The most prominent example of the last category was Schopenhauer. While for Schopenhauer the other arts objectify man's will (and in this way depict the appearances of the world in the form of ideas), music depicts man's will directly (not via the ideas): it is immediate expression of man's will as a general language without concepts. Since music does not depict ideas, but the will, it does not display a shadow, but the will itself in its very being. Hence the effect of music is infinitely stronger compared to the other arts. ${ }^{44}$ From here it is not a great step to the interpretation of music as the most 'romantic' art which the Romantic writers maintained slightly earlier, particularly, again, Hoffmann, for whom music 'is the most romantic of all the arts - one almost wants to say: alone purely romantic. ... Music opens up to man an unknown realm; a world which has nothing in common with the outer world of the senses ...' ${ }^{45}$ Although Hoffmann's emphasis is different from Schopenhauer (who rejected the Romantic philosophers but was of course familiar with Romantic theory of art), the consequence is similar. For Wackenroder, being full of romantic enthusiasm, no art except music is so full of heavenly spirit. But the musical material is at the same time organised and structured, a feature which unfortunately encourages educated men to doing arid and uninspiring analyses. ${ }^{46}$ Hegel also emphasised the realisation of the Romantic [p. 86] through music. By being more subjective than painting, music is the idealisation of the senses through the complete removal of anything spatial, so that the visual is made abstract and transformed to the aural and detached from the material. ${ }^{47}$

Wackenroder's and Hegel's struggle with music as the most romantic, nonvisual, non-spatial and ineffable art, the epitome of the senses on the one hand, and on the other hand music as a most abstract and very disciplined, precise and organised systematic art, reflects a common and characteristic tension in reflections about music. Leonardo Da Vinci disposed of the unsettling qualities of music as a nonspatial, non-visual, ephemeral time-bound art simply by postulating that "painting

\footnotetext{
${ }^{44}$ Schopenhauer, Die Welt als Wille und Vorstellung, book 3, § 52 (2008: 339-341). See also Hamilton (2007: 76-78).

${ }^{45}$ Hoffmann, review of the Fifth Symphony by Beethoven op. 67 (1988: 23) (my translation from the German).

${ }^{46}$ Wackenroder, Das eigentümliche innere Wesen der Tonkunst (2011: 124-125). Similar metaphysical romantic approach to music by Robert Schumann, Schwärmbriefe (1982: 61-65).

${ }^{47}$ Hegel, Vorlesungen über die Ästhetik, Einteilung (1986: 121).
} 
excels and is superior in rank to music, because it does not perish immediately after its creation, as happens with unfortunate music'. ${ }^{48}$ Others decided to say little about the nature of music, but concentrated on the craft of music composition, music making and the anthropological development of music. One of these was Rousseau, who was, as is little known outside the circle of music scholars, a theoretician of music and minor composer besides his work as a political philosopher and homme de lettres. Rousseau also worked as a copyist of music scores throughout most of his life to supplement his income, perhaps the only real profession he had. ${ }^{49}$ In his Dictionnaire de musique (1768) he discusses mainly the craft, science and terminology of music, and says next to nothing about the qualities of music as such. Only in his Essay sur les origines des langues (1781) Rousseau goes more into the elements of music, melody, harmony (and his aesthetic criticism of complex harmonies in then modern music ${ }^{50}$ ), but he really concentrates on the evolution of music from sounds and human utterances. Music has a common origin with language and verse: '... cadence and sounds are born together with syllables ... verse, song, speech have a common origin. ${ }^{51}$

The eighteenth century in its fondness of the nascent natural sciences would have found it attractive to remove the ineffable (later: 'Romantic') element by scientific examination of music and its rational foundation (something Rousseau doubted), but that proved difficult. Diderot spoke of musical sounds as being abstract words, so that every listener can make of them what corresponds to his sentiment in a given point in time. ${ }^{52}$ The [p. 87] aesthetic thinking of the Scottish Enlightenment had little to contribute to the understanding of music, ${ }^{53}$ as had Kant. ${ }^{54}$ One may be tempted to think that this avoidance of a discussion of the essence of music is typical of the early modern period. But also the nineteenth century music theorist Adolf Bernhard Marx, author of a widely used textbook on the composition of music in the nineteenth century and influenced by the aesthetic thinking of Hoffmann and Hegel, says at the beginning of his four-volume treatise that the student must not succumb to the arbitrary choices of a dilettante and to fashionable tastes but has to study

\footnotetext{
${ }^{48}$ Da Vinci (2001: 35).

${ }^{49}$ Gülke (1989: 370).

${ }^{50}$ Rousseau, Essay on the Origin of Languages (1997: 286).

${ }^{51}$ Rousseau, Essay on the Origin of Languages (1997: 282).

${ }^{52}$ Gülke (1989: 433).

${ }^{53}$ See especially, Lord Kames (Henry Home), Elements of Criticism, vol. 1 (1970: 166-170). Reference is made here to the facsimile edition of the first edition of 1762. Like Rousseau, Kames favoured melody over harmony. Kames's friend, Benjamin Franklin, criticised precisely the terseness of the discussion on music in Kames's Elements, see Franklin's letter to Lord Kames, London, $2^{\text {nd }}$ June 1765 , Franklin, Papers, Vol. 12 (1968: 162).

${ }^{54}$ Kant, Kritik der Urteilskraft, book 2, § 53 (Kant 1974: 269, 272-273) [A218-219, 222-223/B221, 225-226]. See Hamilton (2007: 70-72).
} 
thoroughly the works of the great masters, no matter whether they are currently modern or not; only that will educate him in the art and its aesthetics. ${ }^{55}$ The emphasis on study and craftsmanship, instead of philosophical speculation, is noticeable. In short: whatever music is, let us do it well according to the rules of the craft, lege artis, then it will speak for itself and speak to us.

Music can be seen as a kind of language. ${ }^{56}$ That much we can certainly say if we follow Walter Benjamin who regarded every expression of human intellectual life as a kind of language; music is only one example. ${ }^{57}$ But once we want to understand what the language of music tells us, we are quickly thrown back to the philosophicalaesthetic speculations outlined before. ${ }^{58}$ Musicologists have nevertheless attempted to detect and develop a consistent musical equivalent of a vocabulary as in a language, so that music can be defined as a language of expression similar to words, and is not just to be understood metaphorically. ${ }^{59}$ But even eminent composers were sceptical about that. ${ }^{60}$ While music is a [p. 88] language, it does not translate into ordinary language to reveal its meaning. That never stood against drawing parallels between music and poetry and rhetoric in particular, also for the teaching of the proper craft, especially during the time of the Baroque. ${ }^{61}$

\subsection{The lawyers' problem with time and music}

While some philosophical theories are able to incorporate time as a central and foundational element of their system, law finds it extremely difficult to recognise the phenomenon of time. Anyone who now retorts that there are limitation of action rules, regulations on perpetuities in trust law, term of protection provisions for intellectual property rights and the like, has not understood the problem. In such rules the law refers to time as an extraneous structure which a legal institution or relationship is subjected to: after a certain period of time an action to enforce a right can no longer be brought, or copyright expires and the work passes into the public domain. However, the object as it is created/recognised by the law is itself conceptualised as static, immutable. Such an 'object' is particularly property, which is the most relevant legal institution in the present context of music and its protection by copyright. For

\footnotetext{
${ }^{55}$ A. B. Marx, Die Lehre von der musikalischen Komposition, vol. 1 (1868: 13), Dahlhaus (1983: 34$35)$.

${ }^{56}$ Craig and Laroche (2014: 47).

${ }^{57}$ Benjamin, Über Sprache überhaupt (2007: 95).

${ }^{58}$ Jankélévitch (2003: 11), Kivy (1991: 93), Coker (1972: 144-145).

${ }^{59}$ That is what is argued particularly by Cooke (1973: 10-11) et passim.

${ }^{60}$ Cooke $(1973: 11,15)$ on Stravinsky and Hindemith, although Cooke disagrees with them. Critical about music as a language in the usual sense is Hanslick, Vom Musikalisch Schönen (1902: 111-116).

${ }^{61}$ For example, Mattheson, Der vollkommene Capellmeister, §§ 8-11 (2011: 79). See also Knaus and Scholz (1988: 22-25) for the use of terms of rhetoric in the description of elements of musical compositions (motif, theme, melody etc.).
} 
the law, time acts on the object, but is not part of its making. The object is like a statue that gradually decays over the years and will need restoration at some point. This is directly in conflict with the art form of music - music is above all time, as has been said before. Property law, and copyright law in particular, creates notional structures in time, but it cannot deal with a temporal structure, such as music. The way in which the law seeks to incorporate the purely time-bound phenomenon of music in a notionally timeless structure is to freeze specific aspects of music by declaring them as legally relevant elements of protection. In this way the law turns the flow of music into certain static X-ray-like shadows of the breathing musical body to which the protection system of the law is able to attach. ${ }^{62}$

This abstract discussion benefits from a concrete example as an illustration. When a piece of music is performed, one perceives a flow of sounds, one superseded by the other, but in correlation to one another in the listener's mind, and incessantly sustained by the notion of a living force which is, together with the sounds themselves, an instance of the [p. 89] inner awareness of time. ${ }^{63}$ In contrast, copyright law splits apart performance and composition of the music. In relation to the composition the law freezes the compositional flow, itself a time-bound phenomenon, which runs through many stages and drafts, into one final version. In order to be a final version recognised by the law, this version must be recorded or fixed as a 'musical work' (being a technical term of copyright law) with boundaries separating the discrete work from the material of musical inventiveness (or intellectual commons ${ }^{64}$ ) available to any composer. The requirement of recording or fixation, a characteristic feature of copyright law systems, ${ }^{65}$ emphasises the removal of the variability of the piece under the influence of time: ${ }^{66}$ notionally, time is taken out and the music is fixed as an immutable and precisely determinable musical object, the 'musical work' ${ }^{67}$ The performance of the musical composition is a separate act (and separately protected in law) which animates the musical work, but does not make it in law the object of copyright protection: the object of protection is already the written

\footnotetext{
${ }^{62}$ See also Rahmatian (2005: 273, 281, 285).

${ }^{63}$ See above the discussion of Husserl's concept of the phenomenology of the inner awareness of time, Husserl, Phänomenologie des inneren Zeitbewußtseins (2000: 25-27, 63, 99, 101).

${ }^{64}$ See Rahmatian (2011: 111-113) for the specific meaning of the term 'intellectual commons' here: it denotes the reservoir of intellectual material and contribution of collective human creations (for the purpose of the law these are ex nihilo creations, because the term intellectual commons is as much a normative creation as its counterpart, intellectual property). I call 'intellectual commons' all intellectual material, whether protected by copyright or not, and 'public domain' intellectual material that is no longer, or has never been, in copyright. So 'public domain' is a subset of 'intellectual commons'.

${ }^{65}$ For the UK, see Copyright, Designs and Patents Act 1988 (CDPA 1988), s. 3 (2).

${ }^{66}$ Similar also Adorno, Vers une musique informelle (2003a: 516-517): 'The graphical-spatial system of signs locks the successive into simultaneity, into the static.'

${ }^{67}$ In the UK, CDPA 1988, s. 3 (1), partial definition of 'musical work'. See also Rahmatian (2009: 566-569) for the meaning of 'musical work' in law, and below under 3.
} 
piece recorded in a score or recorded on a sound recording as a past musical event: time and the necessary volatility and imprecision which time entails have been removed. By way of this reconceptualisation of the law, the music can become a static 'musical work' and 'propertisation' (i.e. the turning of the music into an object of property ${ }^{68}$ ), or, from a socio-economic [p. 90] perspective, commodification can become possible. ${ }^{69}$ The music, a temporal structure, is depicted, and at the same time replaced, by a 'musical work' in law, which is recognised as an object of property (musical copyright). That is not a temporal structure, but a structure in time: for example, copyright in the musical work in question expires seventy years after the end of the year of the composer's death ${ }^{70}$ - being subject(ed) to time, but not an intrinsic part of it, unlike the living art of music in reality.

During the time of protection the musical work is a static entity in the eyes of the law. It is interesting to note that microeconomic market analysis, which is the basis for the widespread law-and-economics approach to law, also eliminates the element of time and turns the continuum of market forces into artificially frozen and timeless event-points, ${ }^{71}$ for example where supply and demand are supposed to meet in a market equilibrium ${ }^{72}$ with no consideration of the time-related processes before and after. The omnipresent obsession in business with risk management (e.g. through the derivatives trade) in the structuring of financial investments ${ }^{73}$ is, besides a certain narcissistic disposition of man, ${ }^{74}$ ultimately the symptom of an inability to acknowledge the reality of time and the unpredictability of the future which the timeprocess necessitates. In this context, music appears as an unintentionally subversive art form. [p. 91]

Where the composer produces several drafts during the composition process until she declares one of the versions as final, copyright law follows the time-bound

\footnotetext{
${ }^{68}$ A detailed discussion of the 'propertisation' process by copyright law in Rahmatian (2011: 35-43). The word 'propertisation' is unappealing but a useful shorthand reference for this conceptual process. Incidentally, the verb 'to property', though with the different meaning 'to appropriate', existed in the English language until the early seventeenth century, see the relevant entry in the Oxford English Dictionary.

${ }^{69}$ On the criticism of art as a commodity by Adorno (and Marx) in Hamilton (2007: 166-167).

${ }^{70}$ In the EU provided by the Term Directive, Directive 2005/116/EC (amended by Directive 2011/77/EU), Art 1(1), referring to Art 2(1) of the Berne Convention which includes musical works in the definition of 'literary and artistic works'.

${ }^{71}$ Hence for any Law-and-Economics analysis the Classical School of economics with its emphasis on long-term analysis (that is: time) would be a better starting point than the Neo-classical School of economics which effectively eliminates the time factor, see Rahmatian (2013a: 225-226).

${ }^{72}$ E.g. Mankiw (2012: 77).

${ }^{73}$ See e.g. Hudson (2013: 24-27, 1175-1176).

${ }^{74}$ This comprises especially the belief in the immortality of the Ego and the fear of death as not only a likely but a certain event, and, by extension, the fear of risk and the fear of loss of property/money as a narcissistic object-love, see the starting point of this analysis, Freud's article On Narcissism of 1914, Freud (1957: 91) et passim.
} 
creative process and postulates each draft as a copyright-protected musical work in its own right. ${ }^{75}$ Thus the law creates (potentially infinite ${ }^{76}$ ) notional stills of a 'film', similar to the way in which mathematicians conceptualise motion through calculus. ${ }^{77}$ So time and temporal structures, such as music, act in an 'analogous', continuous way, while the law, assuming discrete points, has a 'digital' approach of essentially durationless instants. This is reminiscent of the philosophical paradox in antiquity when the Presocratic philosopher Zeno claimed that a flying arrow is in fact at rest because (at least in Aristotle's controversial interpretation of Zeno's paradox ${ }^{78}$ ) a time period is the sum of indivisible moments with no temporal magnitude. The argument behind this is that, since anything that is occupying a space just in its own size is at rest, the arrow is at rest in each single moment of flight. ${ }^{79}$

\section{The architecture and building blocks of music}

Ephemeral, ineffable and enigmatic as music may be, it nevertheless rests on the firm physical foundation of acoustics, and, in connection, mathematical principles of proportion. ${ }^{80}$ The correlation between mathematical proportion and music - 'How sour sweet music is, when time is broke, and no proportion kept! ${ }^{81}$ - has a long history. The connection between music and proportion exists at least since the Pythagorean School. ${ }^{82}$ This harmonia (i.e. coherent or harmonious relationship) as a [p. 92] principle of order was also considered to be the basis of the movement of the heavenly bodies in a music of the spheres. ${ }^{83}$ Two thousand years later Kepler had the same Pythagorean conviction that the planets from the centre of their orbits follow a 'harmonious' mathematical law which he sought to ascertain in his research: ${ }^{84}$ in this context he discovered what is now called Kepler's third law of planetary motion. ${ }^{85}$ Proportion is also the link between music and architecture, ${ }^{86}$ and between music and

\footnotetext{
${ }^{75}$ Sweeney v. Macmillan Publishers Ltd. [2002] R.P.C. 651 at 666. See also Rahmatian (2005: 283).

${ }^{76}$ Potentially infinite, because the normative border between one 'still' and the next one is determined by copyright-originality, also a normative term, see below, under 4 . To separate one 'still' from another, the new one must be sufficiently 'original' in the copyright sense, and thereby distinguishable.

${ }^{77}$ Devlin (2000: 96, 100-101).

${ }^{78}$ See Lear (1981: 93-98), discussing the probably erroneous interpretation of Zeno's argument by Aristotle.

${ }^{79}$ Aristotle regards this premise as false, see Aristotle, Physics, book 6, ch. 8, at 239b.

${ }^{80}$ See also Kant, Kritik der Urteilskraft, book 2, § 51 (Kant 1974: 263) [A210/B212-213].

${ }^{81}$ Shakespeare, Richard II, Act 5, Scene 4.

${ }^{82}$ Hamilton (2007: 19-24).

${ }^{83}$ Toulmin and Goodfield (1968: 79-81).

${ }^{84}$ Kepler, Harmonies of the World, book 5 (2002: 652) et seq.

${ }^{85}$ Kepler's third law of planetary motion means that the cubes of mean distances of the planets from the sun are proportional to the squares of their periods of revolution.

${ }^{86}$ Padovan (1999: 215) with reference to Leonardo Da Vinci, and Padovan (1999: 267) in relation to early eighteenth century architectural theory.
} 
painting. ${ }^{87}$ The importance of mathematical proportion in music often leads to the inadequate characterisation that music and mathematics are necessarily connected or music is 'applied mathematics'. Not only musicians, also mathematicians reject this popular belief, ${ }^{88}$ but it is true that proportion and patterns (and the recognition of these) are the elements which draw music and mathematics together. ${ }^{89}$

Acoustically the matter is straightforward: a plucked string will oscillate with its fundamental frequency and then gradually the wave nodes of the vibrating string develop: $1,1 / 2,1 / 3,1 / 4$ and so on (that is, the proportions of parts of the string of 1:2, $2: 3,3: 4,4: 5$ etc.), creating the harmonics in intervals of the octave, fifth, fourth, major third, major second and so on. So the major scale is literally "natural' ${ }^{90}$ since it is based on natural intervals (but the construction of the scale as such with their order and selection is obviously a cultural phenomenon). But from then on everything is the product of craft, ingenuity and cultural tradition. We concentrate on Western classical music $^{91}$ when we ascertain the elements of music now. [p. 93]

The elements of music are particularly: tone (pitch and timbre), volume, rhythm, melody, harmony, counterpoint and form. The latter five components depend on the specific type of the composition and the historical period of the music and do not necessarily appear in any one musical piece. What is called here 'elements' or 'components' is the subject-matter of music theory - here understood in the broad sense as the teaching of the appropriate craftsmanship of composition as well as the philosophical and scientific examination of music as an abstract structure. Modern music theory is usually defined more narrowly as dealing with the fashioning principles within musical realisation and comprehension. ${ }^{92}$ However, the physical foundations of music, such as tone and timbre and their perception are commonly examined separately in physics and psychology (acoustics and psychoacoustics).

Pitch and timbre are acoustical phenomena, pitch being the frequency of a sound (e.g. 440 Hertz which is the tone A in today's standard), timbre (sound-colour)

\footnotetext{
${ }^{87}$ Da Vinci (2001: 37): '[M] usic, in its harmonic intervals, makes its suave melodies, which are composed from varied notes. ... the harmonic proportionality of painting is composed simultaneously from various components ...'

${ }^{88}$ Gowers (2002: 130), Hanslick, Vom Musikalisch Schönen (1902: 107-110).

${ }^{89}$ Root-Bernstein (2001: 63, 65), Vaughn (2000: 149).

${ }^{90}$ Roederer (2008: 115-116) on the standing wave modes in a vibrating string. For wind instruments, see Roederer (2008: 135-137).

${ }^{91}$ For the purpose of further discussion of copyright protection of music that will also give sufficient insight into Western jazz and pop music. The following discussion is, however, of limited relevance to non-Western music.

${ }^{92}$ Music theory has been understood as being the philosophical examination of an abstract structure in Antiquity, the Middle Ages and the Renaissance (being musica theorica as opposed to the musica practica: composition manuals dealing with the craft of composing and music making), especially with regard to the connection between mathematical and musical proportion. As from the early nineteenth century, the theoretical-scientific or philosophical approach to music experienced a new upturn. See Dahlhaus, Musiktheorie (1988: 95-98).
} 
being the result of the specific mixture of harmonic components in a (complex) tone. This mixture of harmonics is different for the recorder when compared to the piano, the human voice or the violin, and these specific mixtures give each instrument its characteristic timbre. A computer spectrograph will depict a typical image of the spectrum of partials for each instrument. Or, within different ranges of a single instrument, diverse mixtures of harmonics may appear which are responsible for a different timbre in each range. A good example is the clarinet: the near-absence of the even harmonics $(2,4,6$ etc.) in the low register gives a hollow sound, while the presence of all harmonics in the upper register leads to a sharp sound.

What is called 'volume' in music (indicated as 'piano, forte' etc.) is a combination of acoustics (amplitude of the vibration), and the perception by the ear and processed by the brain (psychoacoustic phenomenon: intensity and loudness). ${ }^{93}$ [p. 94]

Rhythm can be defined as the temporal relation of each note to another as against the background of an arrangement of strong and weak beats (metre) in the flow of measured time. Its constituting elements are measured time and tensions between accented or strong and non-accented or weak beats: this makes the rhythmic accents as projected against the metre, syncopation (a special form of rhythmic accent whereby the accent is shifted from a strong to a weak beat) and so on. ${ }^{94}$ Rhythm is an organisational principle of sounds. ${ }^{95}$ Some methods of musical analysis stress the nature of rhythm as a pattern. ${ }^{96}$

'Melody' is extraordinarily difficult to define. For present purposes it should suffice to say that melody is an organised sequence of sounds that are perceived as intrinsically connected. The smallest unit of a melody is (often) the motif. ${ }^{97}$ In the melody in particular music reveals itself as a temporal structure and as a phenomenon of the inner awareness of fashioned time. ${ }^{98}$

In Western ('art') music the most complex building blocks or elements within music are often harmony and counterpoint (this is obviously entirely dependent on the

\footnotetext{
${ }^{93}$ Roederer (2008: 93-99), and the curves of equal loudness according to Fletcher and Munson, at 98. See also the 'spatial' definition of volume by Coker (1972: 45): 'The volume of a chord refers not to its loudness ... but rather to the measure of the chord's bulk or the musical space occupied by the pitches.' ${ }^{94}$ In fact the matter is more complex, and a generally agreed definition of rhythm probably does not exist. See Hamilton (2007: 127-136) with definitions based on the history of philosophical thought. See further e.g. Cooke (1973: 36), Rahmatian (2005: 269) with a musical example and further references.

${ }^{95}$ Scruton (1997: 22-23) with examples.

${ }^{96}$ Cook (1994: 76-77) on Leonard Meyer's musical analysis method.

${ }^{97}$ On the construction of melodies out of motifs or without motifs from a musical analyst's and composer's perspective, see e.g. De la Motte (1993: 29-44). A not very clear definition of 'melody', but influential, by A. B. Marx, Die Lehre von der musikalischen Komposition, vol. 1 (1868: 26, 28): 'a tonally and rhythmically organised line/series of sounds'. Overview of definitions of 'melody', 'motif', 'theme' etc. in the eighteenth and nineteenth centuries in Knaus and Scholz (1988: 17-19).

${ }^{98}$ See also Scruton (1997: 41) with reference to Husserl, and discussion above under 1.
} 
musical culture, type of music and epoch). In this area the difficult and sophisticated aspects of the craft of music had to be learned by generations of composers to fulfil the standards of the art of their time, and this tradition continues to give these topics a particular weight in music education and musical analysis. The 'musica practica', the practical craft of music composition has here strongly shaped the 'musica theoretica' ${ }^{99}$ Harmony deals with the composition [p. 95] of chords and their relation to one another, that is, the accepted or acoustically and aesthetically desirable progression of chords. These chords are at least triads; the typical musical examples in harmony are however in four parts (soprano/alto/tenor/bass) which corresponds to the mixed chorus (as they developed in the seventeenth century). In harmony there are two viewpoints, that of a composer - how to compose in an artistically acceptable way, and that of an analyst or music theorist - how is a given piece of music harmonically structured. In practical reality harmony consists largely of rules that guide us in which way one achieves a musically satisfying harmonic progression, modulation (key change) and harmonisation of a melody. For instance, in 'classical' harmony octaves, parallel fifths and false relations ${ }^{100}$ must normally be avoided. ${ }^{101}$ Another more complex rule which is a typical example of the 'academic' treatment of harmony is the following one: if the bass part consists of a scale movement of 1-2-3 (e.g. c-d-e), it is to be harmonised with Ib-Vc-I (with a passing 6/4, the second inversion chord), or especially in a choral in the style of Bach, with I-viib-Ib. ${ }^{102}$ If Vc is used, the bass (being the $5^{\text {th }}$ of the second inversion chord) must be doubled. Traditional harmony textbooks are full with such rules. It is not possible and not necessary to go into more detail in this context. ${ }^{103}$

While harmony regards music vertically, being the simultaneous combination of sounds, counterpoint looks at music horizontally as the separate parts in their

\footnotetext{
${ }^{99}$ Or musica theorica. For these terms and their meaning in the early 1500 s, see also Nicola Listenius (1549), quoted in Goehr (1992: 116).

${ }^{100}$ On parallel octaves and fifths, see e.g. De la Motte (2009: 23) with a critical discussion of the usual justifications. See also nineteenth-century discussion by A. B. Marx (1868: 84, 86, 530, 534-535). A false relation is especially the situation that, for example, $d$ appears in the bass part and $d$ sharp in the alto part at the same time (or for some time at the same time), and so creates an augmented prime (socalled chromatic false relation). Such rules depend much on the musical era one looks at. False relations have always been used as an expressive device. A good overview of false relations ('Querstand') in A. B. Marx (1868: 499-506).

${ }^{101}$ One sees in such examples the cultural context of these rules which are often also (rather arbitrarily) extracted from a particular epoch in Western history of music, e.g. the era of J. S. Bach. In modern popular music, for example, this rule has little relevance.

${ }^{102} \mathrm{I}=$ tonic (first degree of the scale), root position of the chord (e.g. c-e-g), $\mathrm{Ib}=$ tonic, first inversion $(\mathrm{e}-\mathrm{g}-\mathrm{c}), \mathrm{Ic}=$ tonic, second inversion $(\mathrm{g}-\mathrm{c}-\mathrm{e}), \mathrm{V}=$ dominant $(\mathrm{g}-\mathrm{b}-\mathrm{d})$ (fifth). $\mathrm{I}=$ major chord, $\mathrm{i}=$ minor chord, etc.

${ }^{103}$ Slightly more discussion in Rahmatian (2005: 269-270). Books on harmony cannot be replaced by single examples and superficial paraphrasing in any case. For a concise description of harmony also for the non-musician, see e.g. Karolyi (1987: 60-84).
} 
melodic development. Counterpoint is the art of [p. 96] setting one or more melodically and rhythmically independent parts (counterpoints) to a given melody (subject), whereby (in classical music) the rules of harmony have to be observed at the same time. Hence progressions of chords in harmony already have an intrinsic movement of the parts: two or more parts move (1) in the same direction (similar motion, motus rectus), (2) in different directions (contrary motion, motus contrarius), (3) one part moves up or down and the other does neither but stays (oblique motion, motus obliquus). In counterpoint, emphasis is on the line of each part, its horizontal melodic aspect and the melodic and rhythmical independence of the different parts, not on the harmonic combination of the sounds, which is (from this perspective) incidental. ${ }^{104}$ Fugues are a prominent example of this technique. Different musical epochs had different rules of counterpoint, ${ }^{105}$ but generally the most influential exposition of the rules of counterpoint is by the Austrian baroque composer Johann Joseph Fux (1660-1741) who distinguished five prototypes ('species') of counterpoint: (1) note against note, (2) two notes against one, (3) four notes against one, (4) two half notes/minims against a whole note/semibreve in form of a ligature (tie) or syncopation, (5) a combination of all species (contrapunctus floridus). ${ }^{106}$ Historically, the relevance of Fux's counterpoint textbook Gradus ad Parnassum is beyond doubt; indeed Haydn and Beethoven learned counterpoint with it. Whether it is pedagogically still satisfactory today, is less clear. ${ }^{107}$ Composition in technical counterpoint ceased before the end of the eighteenth century, except in church music, where it lasted much longer. However, modern classical composers are well familiar with this technique and use or allude to it. ${ }^{108}$ Pop music is more conservative in the use of harmony and counterpoint: whenever a harmonisation of a melody uses a contrary motion (and it typically does), that is a vestige of the old counterpoint. Again, this little outline must suffice here. ${ }^{109}$ [p. 97]

What is 'acceptable' and what are established rules of harmony and counterpoint are aesthetic questions, by no means answered concordantly in various

\footnotetext{
${ }^{104}$ The harmonic aspect of the counterpoint becomes, however, particularly important in the Bach era, see De la Motte (2010: 221-222).

${ }^{105}$ De la Motte (2010: 8).

${ }^{106}$ Fux (1971: 27, 41, 50, 55, 64). Fux's textbook was intended to teach the craft of musical composition, not analytical music theory, see Cook (1994: 25).

${ }^{107}$ De la Motte (2010: 11).

${ }^{108}$ E.g. Whittall (2003: 133-134) (on Hans Werner Henze's Requiem). See also Adorno, Die Funktion des Kontrapunkts in der neuen Musik (2003a: 145).

${ }^{109}$ Slightly more discussion of counterpoint (for copyright analysis) with an example in Rahmatian (2005: 270-271). Harmony and counterpoint can be the basis of large-scale analysis of whole musical pieces in some analytical techniques, such as the Schenkerian analysis method, see Cook (1994: 36): In Schenkerian analysis 'a composition is seen as the large-scale embellishment of a simple underlying harmonic progression ... the same analytical principles that apply to cadences in strict counterpoint can be applied, mutatis mutandis, to the large-scale harmonic structures of complete pieces.'
} 
textbooks, and in any case dependent on the historical basis from which examples of exercises of harmony and counterpoint are drawn. ${ }^{110}$ Both subjects are usually still taught in a somewhat ahistorical way, thus historically frozen sometime in the baroque and classical traditions of Western art music of around 1680-1820. In fact, the rules of harmony and counterpoint changed over the different ages, and modern texts on harmony and counterpoint take account of that. ${ }^{111}$ Harmony and counterpoint rules are distilled and sometimes dry ideal-typical musical grammar. These types exist in classical music (until about the beginning of the twentieth century) but are presented out of a larger musical context and rarely appear in simple purity in real musical pieces. They are nevertheless an indispensable exercise for analysis and compositional craftsmanship, but especially for the creative composer these are rules he/she has to master in order to be able to break them most effectively in the actual creative process. As will be shown, for the copyright lawyer the rules of harmony and counterpoint are a particularly important example of concepts, techniques, 'ideas'. 112

Form is the last important element of music. It is also historically the latest, not because musical pieces did not correspond to certain forms (they did, but generally the forms were rather simple ones), but because it was only in the early nineteenth century that the interest in musical analysis and musical forms rose to a scientific level, partly under the influence of the aesthetics of Hegel and German Idealism. The composition teacher, analyst and aesthetician Adolf Bernhard Marx (1795-1866), following Hegel's path, was here of great importance through his textbooks on composition and music theory. ${ }^{113}$ The subject of form in music discusses the organisation of whole musical pieces by using [p. 98] harmonic, melodic, rhythmic aspects to discover the overall architecture of a piece. ${ }^{114}$ For example, there is the binary form, ternary form, da capo form; ${ }^{115}$ the sonata form, ${ }^{116}$ the symphony, suite, dance (with many sub-categories), variation, the rondo form, concerto, toccata, canon, madrigal, mass and so on. ${ }^{117}$ The aspect of form is an essential starting point for musical analysis. Several types and schools of musical analysis exist. ${ }^{118}$

\footnotetext{
${ }^{110}$ See an instructive statistical example to show that the common rule that in case of root position and first inversion chords the root should be doubled and in the second place the fifth, but the third only sparingly, is incorrect for Bach and the baroque era, De la Motte (2009: 43-44). Here it becomes also apparent that it depends from which composer, which era or which style (Italian, French, German) the rule of harmony in question has been distilled.

${ }^{111}$ De la Motte (2009: 7-8), De la Motte (2010: 7).

${ }^{112}$ See below under 4 .

${ }^{113}$ Cook (1994: 12-13), Dahlhaus (1983: 45).

${ }^{114}$ See e.g. Scruton (1997: 309-312).

${ }^{115}$ Knaus and Scholz (1988: 45-65).

${ }^{116}$ An example of a full analysis of pieces in sonata form in Cook (1994: 260) using some classical and early Romantic works.

${ }^{117}$ A. B. Marx, Die Lehre von der musikalischen Komposition, vol. 3 (1879: 12-13, and ix-xiv) distinguishes in particular between compositions for independent musical instruments and for vocal
} 
The elements or building blocks of music are important for an analysis of the protection of music by copyright because these elements are indicators as to what can be protected by copyright in a work of music, and what cannot. This is especially achieved by the so-called idea-expression dichotomy. ${ }^{119}$

\section{The idea of the 'musical work' in the theory and history of music and its specific meaning in copyright law}

\subsection{The theoretical-historical idea of the 'musical work'}

According to Goehr, music philosophy distinguishes four analytical theories of the musical work. First, the Platonist view: musical works are universals constituted by structures of sounds and exist everlastingly, long before any compositional activity and long after they may have been forgotten. In an Aristotelian view, musical works exist as performances and score-copies. According to the nominalist view, works of music have no form of abstract existence; performances are only classified because they stand in appropriate relations to one another and to score-copies, and [p. 99] this classification is only linguistic for the convenience to refer to certain classes of particulars. The fourth view is the idealist view of musical works (Croce, Collingwood): works are identified with ideas formed in the composer's mind and are then expressed in an objectified form through score-copies or performances which make the works accessible to the public. The work is, however, the musical idea itself, not its objectified expression. ${ }^{120}$ Goehr then characterises the idea of the 'musical work' as a regulative concept, not as a constitutive one: it indicates normatively what should be done in a given artistic genre, not what the fabric of the practice is. The 'musical work' is also an open concept, that is, unbounded, mutable, receptive to continuity, and able to undergo alterations in its definition without losing its identity as new examples come to appear as standard. This is in contrast to closed concepts which refer to their own particular internal, formal, structural or purposeful coherence, for example in justice or property. ${ }^{121}$

\footnotetext{
compositions, and within the former states as separate sub-species the piano etude, the piano fugue, the variation, the small rondo form, the large rondo form, the sonata form, and mixed forms, e.g. the sonata-like rondo, and within the latter category (vocal compositions) classifies into the recitativo, the lied (song), and choral compositions.

${ }^{118}$ Cook $(1994: 27,67,116)$ on formal and psychological approaches to analysis, Schenkerian analysis and so on.

${ }^{119}$ See below under 4.

${ }^{120}$ Goehr (1992: 14-19).

${ }^{121}$ Goehr (1992: 93-94, 102-103).
} 
From that Goehr proceeds to a controversial historical claim: the regulative concept 'musical work' emerged only around 1800; before that time composers did not really have the understanding of what we call 'musical work' today as a result of nineteenth century Romantic aesthetics. Therefore Baroque composers like Bach did not intend to compose musical works, but were, and saw themselves as, craftsmen. ${ }^{122}$ This view has been criticised by several authors. It has been said that Goehr's argument is based on an overstated idea that the concept of music as a fine art emerged under the duress of the romantic cult of personality in the early nineteenth century. But one can see from the sources, without being in danger of an anachronistic reinterpretation, that Baroque composers like Bach or Fux considered their productions as autonomous works of art, ${ }^{123}$ and the same can also be claimed for the seventeenth century and even earlier periods. ${ }^{124}$ Critics also pointed out that the emergence of the idea of the 'work-concept' around 1800 and its dominance from then onwards has to be sought not in the means of production or performance but in the way music was experienced by the audience. ${ }^{125}$ In this debate the real question is probably (to revert to the [p. 100] four different analytical views of musical works outlined before) 'whether the interaction between ideas held about music and the various musical objects or events at hand together generated the various notions of the musical work'. ${ }^{126}$

This argument of a 'Romantic' shift of the understanding of the 'musical work' around 1800 is also relevant to copyright law, because the issue of the interpretation or emergence of the concept of the musical work is intertwined with the issue of authorship. ${ }^{127}$ In the discourse on copyright history the argument of the emergence of the concept of the 'Romantic' author which is claimed to have appeared sometime in the late eighteenth century and which is seemingly responsible for the shaping of the modern copyright laws and their authorship/ownership rules, is wellknown. Both the 'Romantic' author debate among copyright scholars, initiated mostly by Woodmansee and Jaszi, ${ }^{128}$ and Goehr's interpretation of the historical development of the concept of the musical work have common ancestors, particularly Barthes's and Foucault's 'death of the author' idea, ${ }^{129}$ although it must be stressed that neither Barthes and Foucault nor copyright scholars elaborating on the latters' authorship

\footnotetext{
${ }^{122}$ Goehr (1992: 8, 111-115). See also critical discussion of Goehr's claim by Barron (2006: 41-42).

${ }^{123}$ White (1997: 97, 101-102) with the examples of passages from Fux's Gradus ad Parnassum, and Bach's Musical Offering.

124 Butt (2005: 30).

${ }^{125}$ Erauw (1998: 112).

${ }^{126}$ Butt (2005: 38).

${ }^{127}$ Butt (2005: 40, 47-48).

${ }^{128}$ Especially in Woodmansee (1984: 425), Jaszi (1991: 455).

${ }^{129}$ Barthes (1979: 145), Foucault (1991: 101).
} 
concepts devote any discussion to music. ${ }^{130}$ I have criticised elsewhere at length ${ }^{131}$ the highly speculative and unsatisfactory critique of the concept of the 'Romantic author' in copyright scholarship that supposedly governs copyright law principles, is allegedly responsible for a false understanding of authorship in the modern (Internet) world and purportedly hinders the recognition of work collaborations by copyright law. So there is no need to repeat that discussion here. The real effect of the 'Romantic author' critique of a 'traditional' understanding of authorship is ultimately a rejection of any individual creativity and authorship, hence the individual artist (or group of collaborating artists) need not be able to claim copyright protection. This is precisely in line with the interests of large entertainment enterprises, which normally hold copyright ownership in individual [p. 101] authors' works anyway, either by way of assignment or through employee's copyright rules, particularly in the music industry. ${ }^{132}$ In this way, a neo-liberal justification in the appearance of a sophisticated or even subversive critique has been provided, a typical feature of postmodernist theories. $^{133}$

\subsection{The meaning of the 'musical work' in copyright law, and the relevance of 'recording'}

Following Goehr's definition, ${ }^{134}$ one could be tempted to say that the open concept of the 'musical work' in music theory is turned into a closed concept of 'musical work' by copyright law since the law transforms the musical work into an object of property. But matters are not quite that simple. In copyright law, a musical work is not conclusively defined, and it would probably have a sclerotic effect if it were. In UK law a 'musical work' is 'a work consisting of music', exclusive of words and dance ('action') intended to be sung, spoken or performed with the music. ${ }^{135}$ That limitation only denotes that words and dance ${ }^{136}$ are in categories different from 'musical work' (literary work, dramatic work), but does not define 'musical work' further, so this is also an 'open concept'. However, the 'category approach' of copyright systems requires the creation in question to fall into one of the provided legal categories

\footnotetext{
${ }^{130}$ Rahmatian (2011: 157). Barthes does, however, talk about music in Musica Practica, see Barthes (1979: 149) - how illuminating that is, must be decided by the reader (an approach that would possibly obtain Barthes's agreement).

${ }^{131}$ Rahmatian (2011: 149-182).

${ }^{132}$ Rahmatian (2011: 177-180).

${ }^{133}$ See, generally in relation to postmodernism, and particularly in relation to Foucault, Mandosio (2010: 70-74).

${ }^{134}$ Goehr (1992: 93-94, 102-103).

${ }^{135}$ CDPA 1988, s. 3 (1).

${ }^{136}$ Dance is covered superficially only in the legal literature on copyright. This may be the case because the dance community is rather reluctant about asserting rights, and there is as yet no case law on dance, see Waelde, Whatley and Pavis (2014: 218, 224).
} 
(literary work, dramatic work, musical work, artistic work etc.) as a first prerequisite for protection. ${ }^{137}$ Continental European author's rights systems do not have a category approach; their list of work categories is open-ended, but here the differences between the two protection philosophies are in effect not very significant. ${ }^{138}$ The legal meaning of 'musical work' probably comes closest to a nominalist view of [p. 102] the 'musical work' in music theory, with elements of an idealist understanding. ${ }^{139}$

A musical work in copyright law does not coincide with a work of music in music theory. ${ }^{140}$ An illustrative case on this point was Sawkins v. Hyperion. ${ }^{141}$ The musicologist Sawkins prepared a performing edition of some works of the French Baroque composer Michel-Richard de Lalande (1657-1726). He gathered surviving manuscripts and prints scattered in various libraries world-wide, selected the most appropriate version, produced a score and a series of parts which would make the works (grand motets) playable. He also inserted or re-composed missing material, added transcriptions and a figuring to the bass line or a figured bass altogether, all in all 3,000 editorial interventions. ${ }^{142}$ The defendant, a record company which refused to pay Sawkins a royalty or performance fee and was subsequently sued for copyright infringement, claimed, among other things, that Sawkins's editorial interventions did not form part of the music and so he did not create an original musical work which would warrant copyright protection (Lalande's music itself was undisputedly in the public domain). ${ }^{143}$ Leaving aside the separate issue of originality in copyright for now, ${ }^{144}$ the question was whether the restoration by the musicologist to make Lalande's works of Baroque music performable again amounts to a 'musical work' in the sense of copyright. It does, in the opinion of both the High Court ${ }^{145}$ and the Court of Appeal, ${ }^{146}$ which shows that the legal/normative category of musical work does not correspond entirely to what composers, musicians and listeners would normally regard as 'music'; for them this would be Lalande's music, restored. ${ }^{147}$ In fact, Sawkins attempted not to give the impression that he did anything which was not in

\footnotetext{
${ }^{137}$ CDPA 1988, ss. 1 (1) and (2), 3 (1). Time will tell whether this remains the case, see a qualifying statement in relation to the UK category approach in SAS Institute v. World Programming [2013] EWHC 69, para. 27. See also chapter 2 by Charlotte Waelde.

${ }^{138}$ Rahmatian (2011: 53) with further references to French and German law.

${ }^{139}$ See Goehr (1992: 14-19, 93-94, 102-103) and above on this point.

${ }^{140}$ See also on this point, Barron (2006: 43-45).

${ }^{141}$ Sawkins v. Hyperion Records Ltd. [2005] EWCA Civ 565, [2005] RPC 32 (Court of Appeal); [2004] EWHC 1530 (Ch), 2005 RPC 4 (High Court).

${ }^{142}$ An extended discussion of this case by Rahmatian (2009: 560-591) that also takes account of the far more detailed facts.

${ }^{143}$ Sawkins v. Hyperion Records Ltd. [2005] EWCA Civ 565, paras. 24, 42.

${ }^{144}$ See below under 4.

${ }^{145}$ Sawkins v. Hyperion Records Ltd. [2004] EWHC 1530 (Ch), paras. 54, 58.

${ }^{146}$ Sawkins v. Hyperion Records Ltd. [2005] EWCA Civ 565, paras. 36, 43, 45, 49-40.

${ }^{147}$ Rahmatian (2009: 566).
} 
the spirit of Lalande's work, since a restorer must subject his own artistic intentions to those of [p. 103] the artist whose work is to be restored. ${ }^{148}$ So the restorative performing edition prepared by the musicologist is no new music independent from Lalande's (e.g. a variation of it or work inspired by it), which would be considered as a 'musical work' in music theory. When the case was decided, music circles were rather upset, probably because they wrongly assumed that this decision would draw public domain works back into copyright. However, the musical work for which Sawkins could claim copyright is only the narrow area besides the music by Lalande that constitutes his own editorial input. ${ }^{149}$ Everybody is free to create his/her own performing edition on the basis of the existing manuscripts. ${ }^{150}$ This highlights the normative/nominalist aspect of the concept of 'musical work' in copyright law.

However, there is also an idealist aspect to the legal concept 'musical work'. Music is the sound, not the score for the purpose of copyright protection. Case law is unequivocal here: the impact on the ear is more important than the notes written down. ${ }^{151}$ Infringement cannot be determined by a note-for-note comparison of the claimant's and the defendant's work; the notes are essential, but not the sole determinants of what is heard. ${ }^{152}$ Reproduction of a musical work only occurs (and infringement if a substantial part was reproduced) when the substance of [p. 104] the original copyright work is taken, not only when identity is achieved. ${ }^{153}$ 'Music must be distinguished from the fact and form of its fixation as a record of a musical composition. ... But the fixation in the written score or on a record is not in itself the music in which copyright subsists. ${ }^{154}$ Nevertheless, the copyright system of the UK

\footnotetext{
${ }^{148}$ See also Sawkins v. Hyperion Records Ltd. [2005] EWCA Civ 565, paras. 80, 82 where the court likened Sawkins's work to that of a picture restorer.

${ }^{149}$ In copyright law the theoretical rule is clear, and those who raised concerns (also lawyers) in relation to this decision did not seem to have had sufficient understanding of music and/or of UK copyright law, but it is obvious that the application of this principle can cause great problems, because restorations of something that is no longer there in the original or restorations where there may be several options are in reality difficult to separate from the original work (here Baroque music) that is in the public domain.

${ }^{150}$ Sawkins v. Hyperion Records Ltd. [2005] EWCA Civ 565, para. 86: ' $\ldots$ the sort of work done by Dr Sawkins should be encouraged. It saves others the time and trouble of re-creation of near-lost works, but in no sense creates a monopoly in them. If someone wants to use Dr Sawkins's short cut, they need his permission.' (emphasis added). See also Rahmatian (2009: 585-586, 590).

${ }^{151}$ Austin v. Columbia Graphophone Co [1917-23] Macg. Cop. Cas. 398: In that case the defendants had deliberately harmonised the plaintiff's material in the same manner as the plaintiff had done, although they had not taken the actual notes used by the plaintiff. By using the plaintiff's methods of harmonisation they had imitated the plaintiff's work and captured the impression the plaintiff's work created and on which the commercial success was based. Hence there was infringement of copyright. This case was referred to approvingly in Sawkins v. Hyperion Records Ltd. [2004] EWHC 1530 (Ch), para. 57.

${ }_{152}$ Sawkins v. Hyperion Records Ltd. [2004] EWHC 1530 (Ch), para. 57.

${ }^{153}$ Francis Day \& Hunter v. Bron [1963] 1 Ch 587, at 611-612, also with reference to Austin v. Columbia Graphophone Co [1917-23] Macg. Cop. Cas. 398.

${ }^{154}$ Sawkins v. Hyperion Records Ltd. [2005] EWCA Civ 565, para. 53.
} 
requires fixation or recording of a musical work as a prerequisite of protection. ${ }^{155}$ Continental European authors' rights countries do not have such a fixation requirement, so, for example, a piano improvisation is protected by author's right even if not recorded at all. However, there may well be problems of evidence in an infringement action, so that in effect the situation may not be much different from the UK. ${ }^{156}$ But the dualism - (1) the protected music is the perceived sounds, and (2) the score is the reified evidence of the composed musical work ${ }^{157}$ - has features of an idealist interpretation of the 'musical work' in the philosophy of music. While the music may first exist as an idea, it must obtain objectified expression through a score or in a performance, ${ }^{158}$ whereby the performance, being ephemeral, must itself be fixed, for example on a sound recording (which attracts copyright protection in its own right, separate from the recorded music). Imprecise and shadowy as the score is to depict the music as it is to be performed, the law uses this reification as a shorthand reference to the musical work to attach copyright protection and to turn it into a 'definite' and durationless property object.

Copyright law was not always so sure about this. In an old case ${ }^{159}$ the idea that music is the sound, not the score, was taken to its logical conclusion. Music appeals to the ear, while a sheet of music appeals to the eye, hence the performance of the sheet music (in this case by means of a perforated piano roll ${ }^{160}$ ) was held not to be infringement of the [p. 105] copyright in the music. Today this would unquestionably be copyright infringement. ${ }^{161}$

It follows from the present law about musical copyright that any change in the score, for example through an editorial intervention, which has an impact on the acoustical event of the performed music itself ('the totality of the sounds produced by the musicians ${ }^{162}$ ), is potentially a candidate for copyright protection. There will indeed be copyright protection if that intervention or change is also considered as 'original' in the specific meaning of copyright law. ${ }^{163}$ The criterion of originality in copyright law will be discussed now.

\footnotetext{
${ }^{155}$ CDPA 1988, s. 3 (2).

${ }^{156}$ Rahmatian (2011: 54-55) with further references in relation to French and German law.

${ }^{157}$ Rahmatian (2009: 568).

${ }^{158}$ See Goehr (1992: 18).

${ }^{159}$ Boosey v. Whight [1900] 1 Ch. 122 (CA).

${ }^{160}$ The piano roll was not considered as a reproduction of the notes in the sheet music, and was therefore held as not infringing copying of the music, Boosey $v$. Whight [1900] 1 Ch. 122, at 124.

${ }^{161}$ CDPA 1988, s. 17 (2).

162 This is the expression used by the court in Sawkins v. Hyperion Records Ltd. [2005] EWCA Civ 565 , para. 49.

${ }^{163}$ That is what Sawkins v. Hyperion Records Ltd. [2005] EWCA Civ 565, decided with regard to scholarly editions of music, see especially para. 49. See also for more detail, Rahmatian (2009: 568$569)$.
} 

protectable elements

\subsection{The meaning of 'originality' in copyright in relation to works of music}

The requirements for copyright protection of music are that the creation must be a 'musical work', that the musical work must be recorded, ${ }^{164}$ and that it must be 'original' in the meaning of copyright law. ${ }^{165}$ The traditional British approach to originality was that the music must be the result of the author's own skill, labour, effort and judgement, expense and so on. ${ }^{166}$ Effectively the originality requirement acts as a protection of the author against a short-cut or free ride by somebody else, who has not exercised the author's skill and effort. So he does not have the expenses and take the commercial risk and seeks to take over the author's product at a fraction of the cost. Originality in copyright law means, 'not deriving from elsewhere, not being copied'; it does not [p. 106] mean 'creative' or 'artistic'. ${ }^{167}$ On this basis, Sawkins's editorial efforts were accepted as being 'original' for the purpose of copyright protection ${ }^{168}$ in Sawkins v. Hyperion, still the latest principal English case on the subsistence of copyright in musical works. The court specifically pointed out that copyright protection prevents a competitor from making a short-cut. ${ }^{169}$

In the light of recent CJEU/ECJ judgments on the originality criteria in copyright, ${ }^{170}$ the classical UK definition of originality may well have to be qualified. To what extent, is however controversial. According to some views, the CJEU decisions arguably have not changed substantially the originality principles in UK copyright law, ${ }^{171}$ while others detect a sea change. ${ }^{172}$ In any case, greater emphasis will have to be placed on 'judgement' and 'choice' when assessing originality in UK

\footnotetext{
${ }^{164}$ For work and recording/fixation, see above under 3.

${ }^{165}$ CDPA 1988, s. 1 (1) and (2).

${ }^{166}$ The classical decisions are University of London Press v. University Tutorial Press [1916] 2 Ch. 601, at 610, Ladbroke (Football) Ltd. v. William Hill (Football) Ltd. [1964] 1 WLR 273.

${ }^{167}$ See Rahmatian (2011: 38-41, 52-56), discussing specifically the unfair competition aspect of UK copyright protection, and contrasting it with the author's rights approach which insists on a 'personal intellectual creation' or 'the work bearing the stamp of the author' for originality and protection.

${ }^{168}$ And they were considered as 'musical works' in the first place, see discussion above under 3.

${ }^{169}$ Sawkins v. Hyperion Records Ltd. [2005] EWCA Civ 565, para. 86. See also Griffiths (2013: 774775).

${ }^{170}$ Especially the cases Infopaq International v. Danske Dagblades Forening [2009] ECDR 16 (Case C-5/08); Bezpečnostní softwarová asociace v. Svaz softwarové ochrany v Ministerstvo kultury [2011] FSR 18 (Case C-393/09); Painer v. Standard Verlags GmbH, Axel Springer AG, Süddeutsche Zeitung GmbH, Spiegel-Verlag Rudolf Augstein GmbH \& Co. KG, Verlag M. DuMont Schauberg Expedition der Kölnischen Zeitung GmbH \& Co KG [2012] ECDR 6 (C-145/10); Football Dataco Ltd and others v. Yahoo! UK Ltd and others, 1 March 2012 (Case C-604/10), [2012] ECDR 10.

${ }^{171}$ Rahmatian (2013b: 4) for a discussion why effectively the traditional originality criteria of UK copyright will only need slight adjustment following recent CJEU cases.

${ }^{172}$ E.g. Rosati (2013: 47), Griffiths (2013: 780-783).
} 
law to give effect to the CJEU requirements: the composer/author must apply his/her judgement to make selections and choices when he/she creates the work, and through these choices the author expresses original creative ability and thus stamps his/her personal touch on the work. That would reflect the originality test of 'own intellectual creation' in several EU Directives on aspects of copyright ${ }^{173}$ in the interpretation of the CJEU. ${ }^{174}$ [p. 107] Whether this 'new' test moves UK originality closer to the Continental European author's rights concepts of originality, is however most doubtful, ${ }^{175}$ and the decision of Sawkins v. Hyperion shows that. This case has been decided in England and in France on substantially the same facts, ${ }^{176}$ and in both countries the courts gave the musicologist Sawkins copyright/author's rights protection in relation to his performing edition. While the English court could rely on its classical 'skill and labour' originality doctrine, and the principle that copyright protection seeks to prevent making a short cut, ${ }^{177}$ the French court, delivering its judgment a few months earlier, stressed that originality is a relative concept and found no difficulty in attesting the restorer a personal contribution that amounts to genuine creative work. In this way the French court reconciled its decision with the theoretically different originality requirement in French author's rights law. In French author's rights law a work is original if it has the mark of intellectual contribution. The element of personal choice played a role in the assessment of the originality of the intellectual contribution, ${ }^{178}$ here the preparation of a performing edition.

A composer going about the composing of music in a 'traditional' matter, that is, writing a score (probably irrespective of which kind of notation is used), or recording sound patterns in a broad sense, will almost always fulfil the originality requirement for copyright protection, whichever originality test is applied. However, the law struggles in situations of contributions and joint authorship, for example where different band members are involved. Here it shows that the law has [p. 108]

\footnotetext{
${ }^{173}$ Directive 96/9/EC (Database Directive) Art. 3 (1); Directive 2009/24/EC (Software Directive), Art. 1(3); Directive 2001/29/EC (Information Society Directive), Art. 2 (a) (reproduction right); Directive 2006/116/EC (Term Directive), Art. 6 and Recital 16.

${ }^{174}$ See particularly Infopaq International v. Danske Dagblades Forening [2009] ECDR 16 (Case C5/08), para. 45; Painer v. Standard Verlags GmbH and others [2012] ECDR 6 (C-145/10), para. 94; Football Dataco Ltd and others v. Yahoo! UK Ltd and others, 1 March 2012 (Case C-604/10), [2012] ECDR 10, para. 38.

${ }^{175}$ See Rahmatian (2013b: 21-22, 24-27).

${ }^{176}$ Sawkins v. Harmonia Mundi, TGI Nanterre, 1re ch. 19 Janv. 2005: RIDA 1/2006, p. 391. See also, 'Case Comment: Sawkins v. Harmonia Mundi' (2006: 118-119).

${ }^{177}$ Sawkins v. Hyperion [2005] EWCA Civ 565, paras. 36, 42, 86.

${ }^{178}$ Sawkins v. Harmonia Mundi, n. 172 above, 19 Jan. 2005, pp. 4-5: 'une œuvre de l'esprit doit porter la marque de l'apport intellectuel et personnel de l'auteur, peu important son degré d'originalité ... [le demandeur] a dû procéder à des choix artistiques personnels et arbitraires à partir de son interprétation personnelle des cuvres ... l'originalité étant relative, il importe peu que les apports soient disséminés ...' (my emphasis).
} 
difficulties with the fundamentally performative element in music. ${ }^{179}$ The phenomenon of the composer-performer/improvising composer is evidently not a new one - Mozart and Beethoven were among the most celebrated composer-performers of their time. ${ }^{180}$ In jazz and pop music one is frequently confronted with that issue today. The courts rightly distinguish between the composition and the performance, ${ }^{181}$ in line with the copyright statute, ${ }^{182}$ but it becomes a problem to decide when a performance departs so considerably from the composition that it can be regarded as a new, independent musical work. In pop music in particular, a fixed written score that conclusively notes down the composition is uncommon. ${ }^{183}$ The typical court cases concern a musical contribution of one band member (a solo, a drum rhythm) which has an effect on the overall acoustic impression of the performed piece. One case said that a contribution must be 'to the creation of the musical works, not to the performance or interpretation of them' and must 'possess significant creative originality, ${ }^{184}$ to be considered as original (and co-authorship/co-ownership be awarded with an entitlement to a share in the royalties). A joint author/co-composer needs to provide 'a significant creative input' that 'finds its way into the finished work. ${ }^{185}$ So the band member must qualify as a co-composer, not just as a coperformer, even if the composition is the result of improvisatory takes and versions of all performers through which the work is gradually shaped over a period of time. To arrive at a distinction, the improvisation must tip over into a mere performance, the improvisation must have stopped, the composition completed, and the acoustical rendering must have become merely [p. 109] performance of the musical work - an artificial categorisation. Here we have again the problem of the law with temporal structures, movements, developments. ${ }^{186}$ But there are also problems with distinctions as to modality. Is the contribution of a drummer to songs of a pop group part of the musical work (so it may attract copyright protection in form of co-authorship/coownership), or only performance? Or is it only the player of a melody instrument who

\footnotetext{
${ }^{179}$ See on co-authorship/co-ownership in music the extensive discussion in chapter 6 by Alison Firth. See also discussion above under 1 .

${ }^{180}$ Obviously one has to distinguish between the composer-performer who composes first and then performs the composition himself, and the composer who composes by means of performance and improvisation. What Mozart really was (since he seemed to have composed everything in his head anyway) is not so easy to decide, but that was before the copyright era in the Habsburg countries.

${ }^{181}$ Hadley v. Kemp [1999] EMLR 589. Case comment by Arnold (1999: 464); Coffey $v$. Warner/Chappell Music [2005] EWHC 449 (Ch). See also McDonagh (2012: 69-70).

${ }^{182}$ Copyright protection of the composition (musical work): CDPA 1988, ss. 1 (1) (a) and 3 (1); performance (separate rights in performances by the performer, whether this is also the composer or not): CDPA 1988, s. 180 (1) (a).

${ }^{183}$ However, that was unusually the case in Hadley v. Kemp [1999] EMLR 589.

${ }^{184}$ Hadley v. Kemp [1999] EMLR 589, 643-644, 648.

${ }^{185}$ Robin Ray v. Classic FM [1998] FSR 622, 636.

${ }^{186}$ See above under 1.
} 
would be able to qualify, or the singer? It may depend on each band who writes, or co-writes, the songs ('writing' is here understood as encompassing any process of creation), but a drummer can qualify in the view of the courts, at least 'a good drummer' as he 'can significantly influence the whole composition'. ${ }^{187}$ The drummer's contribution was here part of the composition as performed, not of the performance only.

The cases on joint authorship with regard to musical works display a certain anomaly. To qualify for a share in the copyright the claimant must show that he significantly participated in the creation of the musical composition pursuant to a common design, ${ }^{188}$ and his contribution must also be 'original' in the copyright sense, whereby originality is here understood, exceptionally, as demonstrating some artistic ability or creativity. ${ }^{189}$ However, neither in the copyright systems, nor in the author's rights countries 'originality' requires artistic creativity, ${ }^{190}$ and that also applies to the possibly new interpretation of originality by the CJEU: 'own intellectual creation' denotes 'choice' which enables a certain authorial individuality to be reflected in the work; artistic ability, or artistic creativity is irrelevant. ${ }^{191}$ Another example of a certain inclination towards artistic creativity in assessing originality in cases of jointly composed musical works is Fisher v. Brooker. ${ }^{192}$ At issue was, [p. 110] among other things, the eight-bar organ solo played by the band member of Procol Harum, Matthew Fisher, on the Hammond organ at the beginning of the song 'A Whiter Shade of Pale' (1967). The defendant, Gary Brooker, claimed that Fisher's organ solo was only an arrangement of an earlier version of the song by the defendant for voice and piano. However, evidence showed that Mr Fisher was at most building upon 'ideas' used in the course of rehearsal, but was not copying Mr Brooker's piano version. The judge decided that the claimant's organ solo introduction was sufficiently different from what the defendant had composed earlier on the piano to qualify in law, 'and by a wide margin, as an original contribution to the work.' Fisher therefore shared the ownership of the musical copyright in the song as a joint

\footnotetext{
${ }^{187}$ Stuart v. Barrett [1994] EMLR 448, at 460. In that case the court awarded the drummer a share in the copyright of the songs in question.

${ }^{188}$ Stuart v. Barrett [1994] EMLR 448, at 460, following Cala Homes (South) Ltd. v. Alfred McAlpine Homes East Ltd. (No. 1) [1995] FSR 818.

${ }^{189}$ Hadley v. Kemp [1999] EMLR 589, 643-644, 648, Stuart v. Barrett [1994] EMLR 448, at 460. Less specific in Brighton v. Jones [2005] FSR 288 (the case concerned a theatre play, a dramatic work).

${ }^{190}$ See Rahmatian (2011: 54-58, 191-193) for a longer discussion of this complex issue in copyright law. The problem is here that there is now a proliferation of the use of the word 'creativity' well beyond the artistic sector which makes clear distinctions difficult.

${ }^{191}$ See discussion above.

${ }^{192}$ Fisher v. Brooker [2006] EWHC 3239 (Ch), [2007] FSR 12, at 255. The Court of Appeal decision of Brooker v. Fisher [2008] EWCA Civ 287, and the House of Lords decision of Fisher v. Brooker [2009] UKHL 41, 1 WLR 1764, did not reverse or specifically discuss the points relevant here and are therefore disregarded.
} 
author. ${ }^{193}$ This case also indicates a bias towards 'artistic creativity' as a requirement to find for originality. Not only the reference to an original contribution 'by a wide margin' suggests this, but also the judge's consideration as to whether the claimant were entitled to a share in the copyright if his only contribution to the work had been the organ accompaniment to the sung parts. ${ }^{194}$ All that wrangles in the question 'what is (good) art (or music)?' which is normally carefully avoided when the subsistence of copyright is ascertained, ${ }^{195}$ and rightly so, because it is not the courts' business to decide that.

Incidentally, in Fisher v. Brooker it was undisputed that the eight-bar organ solo at issue was inspired by J. S. Bach's second movement of the Third Orchestral Suite in D major (BWV 1068, 'Air on a G String') and a second work by Bach, the cantata 'Wachet auf, ruft uns die Stimme' (BWV 140). ${ }^{196}$ The claimant's piece was sufficiently independent from its models to attract protection in its own right, but the question of 'inspiration' touches on the problem of the idea-expression dichotomy. [p. 111]

\subsection{The concept of the 'idea-expression dichotomy' in copyright law and its application to works of music}

The principle in copyright law is that ideas (concepts, methods, techniques) are not protected by copyright, while expressions (the application of ideas as they specifically manifest themselves in the concrete produced work) are. ${ }^{197}$ This so-called rule of the idea-expression dichotomy is not uncontroversial. ${ }^{198}$ However, despite its ambiguities it is a generally helpful rule for delineating and limiting the extent of the property protection copyright confers, ${ }^{199}$ particularly with regard to music. ${ }^{200}$ The 'elements' or 'building blocks' of music outlined above ${ }^{201}$ are what lawyers would call 'ideas' in copyright law: rhythm, melody, harmony, counterpoint, form, methods of instrumentation in arrangements, and their rules and principles. The problem usually arises in copyright infringement cases because of non-literal copying of a pre-existing

\footnotetext{
${ }^{193}$ Fisher v. Brooker [2007] FSR 12, paras. 40, 42. See McDonagh (2012: 64) for a case comment.

${ }^{194}$ Fisher v. Brooker [2007] FSR 12, para. 41 (in this case the judge did not have to decide this point).

195 Barron (2002: 379-380, 387-388, 399), discussing the more complicated relationship between copyright and art.

${ }^{196}$ Fisher v. Brooker [2007] FSR 12, para. 36.

${ }^{197}$ TRIPs Agreement 1995, Art. 9 (2), Directive 2009/24/EC (Software Directive), art. 1 (2), Designers Guild v. Russell Williams [2001] ECDR 123, para. 25, Bezpečnostní softwarová asociace v. Svaz softwarové ochrany $v$ Ministerstvo kultury [2011] FSR 18 (Case C-393/09), para. 49 (reference to the 'merger doctrine').

${ }^{198}$ Masiyakurima (2007: 555-564).

${ }^{199}$ Rahmatian (2011: 131-135).

${ }^{200}$ A similar discussion, with different examples, can be found in Rahmatian (2005: 285-288), Rahmatian (2009: 574-577), Rahmatian (2011: 133-135).

${ }^{201}$ Above under 2.
} 
work (a slavish copy obviously infringes and does not create any difficulties). It appears that notions of 'storylines', 'historical facts', 'central themes' as instances of non-protectable ideas are easier to grasp than non-protectable concepts of music. ${ }^{202}$ This is also because with music the matter is more difficult: what is actually copied if the subject-matter of protection is supposed to be the sound, not the score? ${ }^{203}$ If 'ideas', that is, building blocks of the craft of music, are taken, and that is entirely inevitable, then the result may well sound similar to the claimant's pre-existing works, and that points towards infringement. Whether there is sufficient similarity is usually ascertained on the basis [p. 112] of whether an ordinary reasonably experienced listener may perceive it that way. ${ }^{204}$ The test of ascertaining recognisably copied melodies can be deceptive; one major psychological problem is that once a melody is recognised, especially if it is a very familiar tune, the differences between the claimant's and defendant's works are soon perceived as immaterial, and infringement is found potentially too readily. ${ }^{205}$ In court trials an assessment of the similarity of two musical works can look like this: ${ }^{206}$

'I have already referred to the fact that the six quavers which form the opening bar of 'Spanish Town' [the plaintiffs' musical work] are ... a commonplace series to be found in other previous musical compositions. Our attention was drawn, for instance, to an Austrian dance tune composed in the early nineteenth century by Von Lichnowsky, the opening bar of which is identical with that of 'Spanish Town.' The same sequence of notes is also to be found in a song entitled 'Let Us Sing Merrily,' although in this case there is a difference of tempo. In these circumstances, the fact that 'Why' [the defendants' musical work] begins with an opening bar containing a similar, though not identical, phrase is of no special significance. By itself it would not be sufficient to warrant the inference that, if the phrase was copied, it was copied from the plaintiffs' work rather than some other composition. What is

\footnotetext{
${ }^{202}$ Cases therefore tend to focus on the non-literal copying of literary/dramatic works: Harman Pictures v. Osborne [1967] 1 WLR 723, Ravenscroft v. Herbert [1980] RPC 193, and more recently, Baigent v. The Random House Group [2007] EWCA Civ 247, [2007] FSR 579, CA ('Da Vinci Codecase').

${ }^{203}$ Francis Day \& Hunter v. Bron [1963] 1 Ch 587, at 608, quoting Austin v. Columbia Graphophone Co [1917-23] Macg. Cop. Cas. 398, at 409; Sawkins v. Hyperion Records Ltd. [2005] EWCA Civ 565, para. 53.

${ }^{204}$ Francis Day \& Hunter v. Bron [1963] 1 Ch 587, at 610,622. As to the reasonable listener standard in the USA, see Baxter v. MCA 812 F.2d 421, and critical comments by Keyes (2003-2004: 431-434).

${ }^{205}$ Discussion of this problem in Craig and Laroche (2014: 61-65) with a model composition for illustration (with audio file at: http://www.iposgoode.ca/?attachment_id=21753), an invention/fugatolike piece containing melodies by Beethoven, Wagner, Britney Spears and Nirvana interwoven in the new piece.

${ }^{206}$ Francis Day \& Hunter v. Bron [1963] 1 Ch 587, at 615-616.
} 
significant is the fact that both in 'Spanish Town' and 'Why' the opening phrase enunciated in the first bar is developed over the remainder of the first eight bars by the use of the same devices or tricks of composition, namely, repetition followed by a pause, followed again by further repetition with a slight variation. It is this circumstance which produces the degree of similarity between the two compositions.'

This passage reveals three problem areas when a pre-existing work A containing ideas (e.g. a harmonic progression I-V-I) realised in the expression of a distinct melody, may be copied and infringed by a work B:

(1) Work B shares the ideas with work A (for example the same harmonic progression), but not the expressions. In that case there is no infringement, but the example is also artificial. Ideas which do not manifest themselves in expressions are in reality impossible. Ideas are [p. 113] (abstract) elements of the musical grammar, for example, the harmonisation technique of a bass part 1-2-3 with Ib-Vc-I, types of cadences, a counterpoint part in the form of two notes against one in oblique or contrary motion, ${ }^{207}$ figured bass, ${ }^{208}$ accompaniment and tune formulae (also ornamentation formulae), rhythmic structures, structures of form (A-B-A form, variation, canon, dance), potentially (but with caution) standards in jazz ${ }^{209}$ and so forth. Where a composer invents his own grammar or elements as part of a new composition technique, that could be expression, because the composer would be in the position of a 'writer who must provide specially vocabulary and syntax for each sentence he writes. ${ }^{210}$ But if that technique becomes common standard over time (like twelve-tone music, which re-used old composition methods anyway) it will probably be considered as an idea. All these 'ideas' in the copyright sense can only enter the acoustically perceivable material world if they assume some representation or reification which is a form of expression in itself, embodied in some kind of fixation. ${ }^{211}$ In theory, if the expression merely renders the idea, and does not add anything at all to it, then this expression cannot attract protection. ${ }^{212}$ So the chord $\mathrm{f}$-a-

\footnotetext{
${ }^{207}$ See above under 2.

${ }^{208}$ Discussion of the figured bass in Sawkins v. Hyperion Records Ltd. [2004] EWHC 1530 (Ch.), para. 15. See also Rahmatian (2009: 574).

${ }^{209}$ Craig and Laroche (2014: 48) on borrowing (in jazz and generally) and the potential artificiality of the interpretation that copyright requires.

${ }^{210}$ Instructive in Adorno, Philosophie der Neuen Musik (2003b: 101).

${ }^{211}$ See also Donoghue v. Allied Newspapers [1938] 1 Ch. 106, at 110.

212 This is the 'merger doctrine' (especially in the United States): if there is only one way of expressing an idea, no protection is given, because otherwise any protection of the expression would in fact give protection to the idea, see e.g. Kregos v. Associated Press, 937 F.2d 700, 705 (CA-NY, 2nd Cir.1991). Now also at EU level in Bezpečnostni softwarová asociace v. Svaz softwarové ochrany v Ministerstvo kultury [2011] FSR 18 (Case C-393/09), para. 49.
} 
$\mathrm{c}$ is only the idea 'F-major chord' rendered acoustically or in writing. But what is the situation with an extremely standard harmonic progression vi-ii-V-I? The concept (viii-V-I) will be unprotectable idea, but its realisation (and there are several possibilities to do that) potentially could be. Distinctiveness or idiosyncrasy in the application of this harmonic progression (especially in combination with rhythmic and melodic elements) tends towards copyright protection. ${ }^{213}$

So what aspect of the material infringes (expression taken from a pre-existing work which is also a substantial part of it) and what aspect is [p. 114] available to all (idea, such as concepts of harmonic progression in principle)? It is a legal/normative decision by the courts whether vi-ii-V-I really manifests only an 'idea' and does not (also) contain an expression: thus the 'idea' is not merely detected, it is made. ${ }^{214}$ The 'idea' is conceptually a kind of Kantian thing-in-itself or Ding an sich that is incapable of being observed, ${ }^{215}$ being an abstraction deduced (or reduced) from its physical manifestation/representation or 'expression'. Thus what we perceive is either a manifestation of the 'idea' (no protection) or a manifestation of an expression, based partly on the idea but something added to it (copyright protection). ${ }^{216}$ What is what is ultimately decided by the court in the individual case. However, some guidance as to which elements constitute unprotectable ideas give descriptions in music theory and analysis of a conceptual framework of a specific piece, for example: ${ }^{217}$

'The materials that mark the two thematic areas of [Beethoven's piano sonata] Op. 49/2 are not only similar texturally (that is obvious) but melodically too: Fig. 128 shows this. And there is also a rhythmic similarity between the upper parts of bars 3 and 27. On the other hand the two themes are distinct harmonically in that the A theme is quite discursive with its implied $\mathrm{V}^{7}$ of IV, whereas the $\mathrm{B}$ theme hugs its tonic closely (everything is either a D major chord or resolves directly to one).'

What is characteristic here is that this description is a 'reverse-engineered' abstraction of the expression for the purpose of research and analysis, but it is not the expression itself, because nobody would be able to perform the music on the basis of this

\footnotetext{
${ }^{213}$ Francis Day \& Hunter v. Bron [1963] 1 Ch 587, at 616 (in the passage following from the quote above).

${ }^{214}$ As Lord Hailsham put it in L.B. Plastics v Swish Products Ltd. [1979] RPC 551, 629: 'it all depends on what you mean by "ideas".

${ }^{215}$ Kant, Prolegomena zu einer jeden künftigen Metaphysik (Prolegomena to any future Metaphysics) $\S 13$, note II (1995: 47).

${ }^{216}$ See also Designers Guild v. Russell Williams [2001] ECDR 123, para. 25: '[E]very element in the expression of an artistic work ... is the expression of an idea on the part of the author.' (per Ld Bingham).

${ }^{217}$ Cook (1994: 266).
} 
description. ${ }^{218}$ That non-reversibility indicates that the description does not denote the actual protectable expression but the underlying unprotectable idea or part of it. ${ }^{219}$

\section{[p. 115]}

(2) Work B shares the ideas with work A, and takes over a part of the expressions of the work A. If that part is also a substantial part (or sufficient to make the individuality of the original author appear in the section taken), then there will be infringement. But, as the quotation above shows, the more commonplace a phrase or melody is, although capable of being copyright-protected in principle, the more it tends to be shifted towards unprotectable ideas, or alternatively, the more it is regarded as a work not originating from the claimant but from somewhere else, typically with no definite pedigree. In either case infringement would be denied. In that connection the blunt nature of the instrument 'copyright' reveals itself particularly well: work B sharing a substantial part of expressions in work A indicates infringement, but not necessarily 'stealing' in a musical/aesthetic sense. The concepts of copyright cannot accommodate creative musical borrowing (whether or not transformative), as it always occurred in musical history and as it appears currently widely in music sampling, for example in hip hop music. ${ }^{220}$

(3) Work B shares the ideas with work A, and deliberately takes over a part of the expressions of the work A as a basis for a new work, for example an arrangement (adaptation) of work $\mathrm{A}$ in form of an orchestration or a variation work. The part taken over in work B is certainly a substantial part, and if there is no permission (licence) from the copyright owner of work A, then there will be infringement. However, work $\mathrm{B}$ is sufficiently independent and original (in the copyright sense) that it attracts copyright in its own right to the extent to which it does not infringe work A (in the same way as an unauthorised translation of a novel into another language). For example, if, by comparison with the original protected work, an arrangement exhibits a sufficient degree of originality, then it is capable of being a separate copyright work and obtains protection, and the degree of originality is no different from what is required to establish copyright in any other work. ${ }^{221}$ Where work B was only inspired by work $\mathrm{A}$, there is no infringement at all. ${ }^{222}$ The separate nature (and copyright protection) of orchestral arrangements, for example, is not in doubt as [p. 116]

\footnotetext{
${ }^{218}$ But one would be able to on the basis of the extract of the score in fig. 128 that has been mentioned).

${ }^{219}$ See also Rahmatian (2011: 134-135), and Rahmatian (2005: 287) with different examples, including one from a letter by Mozart describing in words the realisation in his composition of a dramatic scene in the Abduction from the Seraglio.

${ }^{220}$ Arewa (2005-2006: 547, 550, 558, 579-586, 610-612, 615-618, 624-628, 630-634).

${ }^{221}$ Fisher v. Brooker [2007] FSR 12, para. 44.

${ }^{222}$ Fisher v. Brooker [2007] FSR 12, para. 36, leaving aside that J. S. Bach's music is not protected by copyright anyway.
} 
such, ${ }^{223}$ but what is simple adaptation and what is sufficiently independent work (or contribution) is a matter of fact and degree, ${ }^{224}$ and is ultimately decided by the court in each individual case. We are also confronted here again with the issue as to when a musical performance of work A departs so significantly from the canon of acceptable performances that it could be regarded as an independent new work $\mathrm{B},{ }^{225}$ being an adaptation or arrangement of the work $\mathrm{A}$, and therefore attracting copyright as a composition in its own right. ${ }^{226}$

\section{Copyright transforming the work of music into a 'musical work' and property right: does that reflect the composers' and performers' idea of music?}

Music is an entirely time-dependent process, a temporal structure; it reflects the inner awareness of time, is abstract and ephemeral, and naturally cannot be possessed and allocated. However, that is what the law in its property system, that is, copyright system, seeks to do when it grants protection for 'music'. The law transforms the music into discernable and static entities, 'musical works', to which legal rights can attach, in some ways like a ladle having scooped water from a flowing brook to make the water controllable and capable of being owned. The emphasis on the notation, the writing or fixation as a prerequisite for copyright protection, underlines this, although the law acknowledges that the written notes are not the music, it is the performed sound. The sound recording counteracts the fleeting nature of music today, far more than the classical written score could ever do: ${ }^{227}$ music becomes an available object and is no longer a fashioned period of time only. The 'musical work' is a normative definition, overlapping, but not coinciding with what musicians regard as music. This definition uses aspects of the [p. 117] elements of music, such as melody, harmony, counterpoint, form, but not systematically, and these building blocks of music are designed to create music, not legal protection, so they are of limited use as a basis for establishing copyright protection. Copyright law also divides composition from performance and allocates different rights to either, although in reality one precipitates the other and they are often inseparable in the creative process, for

\footnotetext{
${ }^{223}$ Godfrey v. Lees [1995] EMLR 307, Beckingham v. Hodgens [2002] EWHC 2143 (Ch), [2002] EMLR 45.

${ }^{224}$ As one can see from the reasoning of Fisher v. Brooker [2007] FSR 12, paras. 41-42.

${ }^{225}$ Compare the discussion in chapter 3 by Martin Parker Dixon on the interpretation of J. S. Bach's by Glenn Gould, turning Bach into 'Gould's Bach'. With Gould's interpretation of Mozart's piano music this is definitely true, in various ways.

${ }^{226}$ Coffey v. Warner/Chappell Music [2005] ECDR 21.

${ }^{227}$ Ashby (2010: 28-33).
} 
example in improvisation. As a result, authorship and entitlement (copyright ownership, especially to found claims to royalties) become difficult to ascertain, particularly in the usual scenario of collaboration of several composers/performers or 'musicians'. 228

The legal transformation of music into 'musical works' by copyright law and the factual transformation of music into recorded past musical performances by sound recordings are essential to the commodification and commercialisation of music. ${ }^{229}$ Copyright reflects the composers' and performers' idea of music very imperfectly only. However, it is doubtful whether copyright law intends to reflect fully the nature of music and music performance in its protection mechanism for music. What it does, and it seems that this is the predominant concern, is to create a notional black box of property into which the art of music is squeezed to render it a controllable object of property that can be owned, defended against infringers, transferred against payment and commodified in other ways, for example (increasingly) in the form of speculation. Therefore the law apparently does not need to have a too sophisticated understanding of the object of protection, the music. Whether the art of music making suffers through this treatment is secondary because once the music is an object of property, a price can be put to it and a commercial value allocated which is essential to business and commercialisation. The copyright-protected musical work is then similar to a share in a company, not expressing the true quality of the enterprise and its products, but having a notional value, perceived or fixed by the market (e.g. the stock exchange) at a given time, and largely independent from any intrinsic and possibly non-pecuniary values of the company. So the black box of copyright property may not have to contain much 'art' or 'music' at all, and discussions about whether the quality of modern music of all styles is promoted or damaged by copyright and the music business, can become redundant, because these aspects can be relegated to aesthetic quibbles of an irrelevant élite of artists and art critics. The cultural industries [p. 118] effectively have operated on this basis for a long time. ${ }^{230}$ Even an empty shell is perceived as valuable, so long as it is alienable against money. Obviously, one cannot blame copyright for that: copyright is just a tool, used and shaped by human actors. It depends on them which task copyright is supposed to fulfil. If copyright is meant to be a commodification device for music, then it plays its role well. If copyright is understood as a gentle protective support for the unique art form of music and its creators, then it needs substantial retuning.

\footnotetext{
${ }^{228}$ See chapter 6 by Alison Firth.

${ }^{229}$ Rahmatian (2005: 274-275, 285, 288) with further references.

${ }^{230}$ A famous critic of this state of affairs was Adorno, as is well known. See e.g., Horkheimer and Adorno, Dialektik der Aufklärung (1986: 118-129) (The section on the cultural industry 'Kulturindustrie' - is likely to have been written mostly by Adorno).
} 


\section{Bibliography}

Adorno, Theodor W. (2003a), Musikalische Schriften I-III: Klangfiguren, Quasi una fantasia, Musikalische Schriften III (Gesammelte Schriften Band 16), Frankfurt am Main: Suhrkamp

Adorno, Theodor W. (2003b), Philosophie der neuen Musik (Gesammelte Schriften Band 12), Frankfurt am Main: Suhrkamp

Arewa, Olufunmilayo B. (2005-2006), 'From J. C. Bach to Hip Hop: Musical Borrowing, Copyright and Cultural Context', 84 North Carolina Law Review 547-645

Arnold, Richard (1999), 'Are performers authors?', 21 European Intellectual Property Review, 464-469

Ashby, Arved (2010), Absolute Music, Mechanical Reproduction, Berkeley and Los Angeles: University of California Press

Barron, Anne (2002), 'Copyright Law and the Claims of Art', 4 Intellectual Property Quarterly, 368-401

Barron, Anne (2006), 'Introduction: Harmony or Dissonance? Copyright Concepts and Musical Practice', 15(1) Social \& Legal Studies, 25-51

Barthes, Roland (1979), 'Musica Practica', in Stephen Heath ed. and trans., Image-MusicText, Glasgow: Fontana/Collins, pp. 149-154

Barthes, Roland (1979), 'The Death of the Author', in Stephen Heath ed. and trans., ImageMusic-Text, Glasgow: Fontana/Collins, pp. 142-148

Benjamin, Walter (2007), 'Über Sprache überhaupt und über die Sprache des Menschen', in Hartmut Böhme and Yvonne Ehrenspeck (eds), Walter Benjamin, Aura und Reflexion. Schriften zur Kunsttheorie, Frankfurt am Main: Suhrkamp, pp. 95-110

Bent, Margaret (1997), 'Polyphony of Texts and Music in the Fourteenth-Century Motet: Tribum que non abhorruit/Quoniam secta latronum/Merito hec patimur and Its "Quotations", in: Dolores Pesce (ed.), Hearing the Motet. Essays on the Motet of the Middle Ages and Renaissance, New York, Oxford: Oxford University Press, pp. 82-103

Brendel, Alfred (2011), On Music. Collected Essays, London: Robson Books

Butt, John (2005), 'The seventeenth-century musical work', in Tim Carter and John Butt (eds), The Cambridge History of Seventeenth-Century Music, Cambridge: Cambridge University Press, pp. 27-54

Butt, John (2010), 'Do Musical Works Contain an Implied Listener? Towards a Theory of Musical Listening', 135(1) Journal of the Royal Musical Association, 5-18

Case Comment: Sawkins v. Harmonia Mundi (2006), 37 International Review of Intellectual 
Property and Competition Law, 116-122 [no author]

Coker, Wilson (1972), Music and Meaning. A Theoretical Introduction to Musical Analysis, New York: The Free Press

Cook, Nicholas (1992), Music, Imagination, and Culture, Oxford: Oxford University Press

Cook, Nicholas (1994), A Guide to Musical Analysis, Oxford: Oxford University Press

Cooke, Deryck (1973), The Language of Music, London: Oxford University Press

Craig, Carys and Laroche, Guillaume (2014), 'Out of Tune: Why Copyright Law Needs Music Lessons', in Courtney Doagoo, Mistrale Goudreau, Madelaine Saginur and Teresa Scassa (eds), Intellectual Property for the $21^{\text {st }}$ Century. Interdisciplinary Approaches, Toronto: Irwin Law, pp. 43-71

Da Vinci, Leonardo (2001), Leonardo On Painting, Martin Kemp (ed.), New Haven and London: Yale University Press (Yale Nota Bene)

Dahlhaus, Carl (1983), Analysis and Value Judgment, tr. Siegmund Levarie, New York: Pendragon Press

Dahlhaus, Carl (1988), 'Musiktheorie', in: Carl Dahlhaus (ed.), Einführung in die systematische Musikwissenschaft, Laaber: Laaber Verlag, pp. 93-132

Daniélou, Alain (1949), Northern Indian Music. Vol. 1, London: Christopher Johnson, Calcutta: Visva Bharati

De la Motte, Diether (1993), Melodie. Ein Lese und Arbeitsbuch, München; Kassel, Deutscher Taschenbuch Verlag; Bärenreiter Verlag

De la Motte, Diether (2009), Harmonielehre, $15^{\text {th }}$ ed., Kassel-Basel: Bärenreiter

De la Motte, Diether (2010), Kontrapunkt, $8^{\text {th }}$ ed., Kassel-Basel: Bärenreiter

Devlin, Keith (2000), The Language of Mathematics. Making the Invisible Visible, New York: W. H. Freeman and Co.

Donington, Robert (1992), The Interpretation of Early Music. New Revised Edition, New York and London: W. W. Norton \& Co

Erauw, Willem (1998), 'Canon Formation: Some More Reflections on Lydia Goehr's Imaginary Museum of Musical Works', 70(2) Acta Musicologica, 109-115

Foucault, Michel (1991), 'What is an author?', in Paul Rabinow (ed.), The Foucault Reader, London: Penguin, pp. 101-120

Franklin, Benjamin (1968), The Papers of Benjamin Franklin, Leonard W. Labaree ed.), vol. 12, New Haven and London: Yale University Press

Freud, Sigmund (1957), 'On Narcissism: An Introduction', in James Strachey (ed), The Standard Edition of the Complete Psychological Works of Sigmund Freud, Vol. XIV (1914- 
1916), London: The Hogarth Press, 73-102

Fux, Johann Joseph (1971), The Study of Counterpoint from Johann Joseph Fux's Gradus ad Parnassum, trans. and ed. Alfred Mann, New York and London: W. W. Norton

Gadamer, Hans-Georg (2003), Truth and Method. Second, revised Edition, tr. Joel Weinsheimer and Donald G. Marshall, New York: Continuum

Goehr, Lydia (1982), 'Being True to the Work', 47(1) The Journal of Aesthetics and Art Criticism, 55-67

Goehr, Lydia (1992), The Imaginary Museum of Musical Works. An Essay in the Philosophy of Music, Oxford: Clarendon Press

Gowers, Timothy (2002), Mathematics. A Very Short Introduction, Oxford: Oxford University Press

Griffiths, Jonathan (2013), 'Dematerialization, Pragmatism and the European Copyright Revolution', 33 (4) Oxford Journal of Legal Studies, 767-790

Gülke, Peter (1989), 'Rousseau und die Musik oder Von der Zuständigkeit des Dilettanten', in Peter Gülke (ed.), Jean-Jacques Rousseau: Musik und Sprache, Leipzig: Reclam, pp. 331522

Hamilton, Andy (2007), Aesthetics and Music, London and New York: Continuum

Hanslick, Eduard (1902), Vom Musikalisch-Schönen. Ein Beitrag zur Revision der Ästhetik der Tonkunst, $10^{\text {th }}$ ed., Leipzig: Verlag von Breitkopf und Härtel

Hegel, Georg Wilhelm Friedrich (1986), Vorlesungen über die Ästhetik I (Werke 13), Frankfurt am Main: Suhrkamp

Hoffmann, Ernst Theodor Amadeus (Wilhelm) (1988), Schriften zur Musik. Singspiele, Berlin und Weimar: Aufbau Verlag

Horkheimer, Max, and Adorno, Theodor W. (1986), Dialektik der Aufklärung, Frankfurt am Main: Fischer Taschenbuch Verlag

Hornbostel, Erich Moritz von (1986), Tonart und Ethos. Aufsätze, Leipzig: Reclam

Hudson, Alastair (2013), The Law of Finance, $2^{\text {nd }}$ ed., London: Sweet \& Maxwell

Husserl, Edmund (2000), Vorlesungen zur Phänomenologie des inneren Zeitbewußtseins, ed. Martin Heidegger, Tübingen: Max Niemeyer Verlag

Husserl, Edmund (2009), Ideen zu einer reinen Phänomenologie and phänomenologischen Philosophie, Hamburg: Felix Meiner Verlag

Jankélévitch, Vladimir (2003), Music and the Ineffable, tr. Carolyn Abbate, Princeton and Oxford: Princeton University Press

Jaszi, Peter (1991), 'Toward a Theory of Copyright: The Metamorphoses of “Authorship"', 
1991(2), Duke Law Journal, 455-502

Kames, Lord Kames (Henry Home) (1970), Elements of Criticism, vol. 1, Hildesheim, New York: Georg Olms Verlag (facsimile edition of the first edition of 1762)

Kant, Immanuel (1974), Kritik der Urteilskraft, (Werkausgabe, Band 10), W. Weischedel (ed.), Frankfurt am Main: Suhrkamp Verlag

Kant, Immanuel (1995), Prolegomena zu einer jeden künftigen Metaphysik, die als Wissenschaft wird auftreten können, Stuttgart: Reclam

Karolyi, Otto (1987), Introducing Music, Harmondsworth: Penguin

Kepler, Johannes (2002), 'Harmonies of the World. Book Five', in S. Hawking (ed.), On the Shoulders of Giants: The Great Works of Physics and Astronomy, Philadelphia, London: Running Press, pp. 635-723

Keyes, J. Michael (2003-2004), 'Musical Musings: The Case for Rethinking Music Copyright Protection', 10 Michigan Telecommunications and Technology Law Review, 407-444

Kivy, Peter (1991), Music Alone. Philosophical Reflections on the Purely Musical Experience, Ithaca and London: Cornell University Press

Kivy, Peter (1995), Authenticities: Philosophical Reflections on Musical Performance, Ithaca, London: Cornell University Press

Kivy, Peter (2007), Music, Language, and Cognition and Other Essays in the Aesthetics of Music, Oxford: Oxford University Press

Knaus, Herwig and Scholz, Gottfried (1988), Formen in der Musik, Vol. 1, Wien: Österreichischer Bundesverlag

Kristeller, Paul Oskar (1952), 'The Modern System of the Arts: A Study in the History of Aesthetics (II)', 13(1) Journal of the History of Ideas, 17-46

Kubik, Gerhard (1988), Zum Verstehen Afrikanischer Musik, Leipzig: Reclam

Lear, Jonathan (1981), ‘A Note on Zeno’s Arrow', 26 Phronesis, 91-104

Mandosio, Jean-Marc (2010), Longévité d'une imposture: Michel Foucault, Paris: Éditions de L'Encyclopédie des Nuisances

Mankiw, N. Gregory (2012), Principles of Economics, $6^{\text {th }}$ ed. (International Edition), Mason O: South Western, London: Cengage Learning

Marx, Adolf Bernhard (1868), Die Lehre von der musikalischen Komposition, praktisch theoretisch, Erster Theil, $7^{\text {th }}$ ed. Leipzig: Breitkopf und Härtel

Marx, Adolf Bernhard (1879), Die Lehre von der musikalischen Komposition, praktisch theoretisch, Dritter Theil, $5^{\text {th }}$ ed. Leipzig: Breitkopf und Härtel

Masiyakurima, Patrick (2007), 'The futility of the idea/expression dichotomy in UK 
copyright law', 38 (5) International Review of Intellectual Property and Competition Law, $548-572$

Mattheson, Johann (2011), 'Der vollkommene Kapellmeister' (extracts), in Frieder von Ammon and Elisabeth Böhm (eds), Texte zur Musikästhetik, Stuttgart: Reclam, pp. 76-92

McDonagh, Luke (2012), 'Case Comment: Rearranging the Roles of the Performer and the Composer in the Music Industry: the potential significance of Fisher v. Brooker', 1 Intellectual Property Quarterly, 64-76

Nettl, Bruno (1983), The Study of Ethnomusicology. Twenty-nine Issues and Concepts, Urbana and Chicago: University of Illinois Press

Padovan, Richard (1999), Proportion. Science, Philosophy, Architecture, London and New York: E. \& F. N. Spon

Rahmatian, Andreas (2005), 'Music and Creativity as Perceived by Copyright Law', 3 Intellectual Property Quarterly, pp. 266-293

Rahmatian, Andreas (2009), "The Concepts of "Musical Work" and "Originality" in UK Copyright Law - Sawkins v. Hyperion as a Test Case', 40(5) International Review of Intellectual Property and Competition Law, 560-591

Rahmatian, Andreas (2011), Copyright and Creativity. The Making of Property Rights in Creative Works. Cheltenham: Edward Elgar

Rahmatian, Andreas (2013a), 'A Fundamental Critique of the Law-and-Economics Analysis of Intellectual Property Rights', 17(2) Marquette Intellectual Property Law Review, 191-229 Rahmatian, Andreas (2013b), 'Originality in UK Copyright Law: The Old "Skill and Labour" Doctrine Under Pressure', 44 International Review of Intellectual Property and Competition Law, 4-34

Roederer, Juan G. (2008), The Physics and Psychophysics of Music. An Introduction, $4^{\text {th }}$ ed., New York: Springer

Root-Bernstein, Robert S. (2001), 'Creativity and Scientific Thinking', 34(1) Leonardo, 6368

Rosati, Eleonora (2013), 'Towards an EU-wide Copyright? (Judicial) pride and (legislative) prejudice', 1 Intellectual Property Quarterly, 47-68

Rousseau, Jean-Jacques (1997), 'Essay on the Origin of Languages in which Something is said about Melody and Musical Imitation', in Victor Gourevitch (ed.), Jean-Jacques Rousseau, The Discourses and other early political writings, Cambridge: Cambridge University Press, pp. 247-299

Schopenhauer, Arthur (2008), Die Welt als Wille und Vorstellung, München: Deutscher Taschenbuch Verlag 
Schumann, Robert (1982), Schriften über Musik und Musiker, ed. Josef Häusler, Stuttgart: Reclam

Scruton, Roger (1997), The Aesthetics of Music, Oxford: Oxford University Press

Stambaugh, Joan (1964), 'Music as a Temporal Form', 61(9) The Journal of Philosophy, 265280

Toulmin, Stephen and Goodfield, June (1968), The Fabric of the Heavens, Harmondsworth: Penguin

Vaughn, Kathryn (2000), 'Music and Mathematics: Modest Support for the Oft-Claimed Relationship', 34(3/4) Journal of Aesthetic Education, 149-166

Wackenroder, Wilhelm Heinrich (2011), 'Das eigentümliche innere Wesen der Tonkunst und die Seelenlehre der heutigen Instrumentalmusik', in Frieder von Ammon and Elisabeth Böhm (eds), Texte zur Musikästhetik, Stuttgart: Reclam, pp. 122-132

Waelde, Charlotte, Whatley, Sarah, Pavis, Mathilde (2014), 'Let's dance! - but who owns it?', 36(4) European Intellectual Property Review, 217-228

Wellek, Albert (1963), Musikpsychologie und Musikästhetik. Grundriss der Systematischen Musikwissenschaft, Frankfurt am Main: Akademische Verlagsgesellschaft

White, Harry (1997), “'If It's Baroque, Don’t Fix It:” Some Reflections on Lydia Goehr's "Work-Concept" and the Historical Integrity of Musical Composition', 69(1) Acta Musicologica, 94-104

Whittall, Arnold (2003), Exploring Twentieth-Century Music, Cambridge: Cambridge University Press

Wiora, Walter (2000), 'Der Grundbegriff Kunstwerk. Versuch einer wissenschaftlichen Klärung', 31(1) International Review of the Aesthetics and Sociology of Music, 7-51

Woodmansee, Martha (1984), 'The Genius and the Copyright: Economic and Legal Conditions of the Emergence of the "Author", 17(4) Eighteenth-Century Studies, 425-448 